397 肝及び肝癌組緎内蛋白質燐酸化醅素Cアイン ザイムの免疫組織化学的及び免䝘電顕的研究

福里利夫, 町並陸生

(東京大学医学部病理)

蛋白質酸化素C (PKC)を介丁る細胞内情報伝達采 の重要古役割が明かになりつつある。最近，PKCK いくつかのフインザイムが存在するととが明らかに友 った。PKCの多榛な役割はそれらのアインザイムの組 穖及び細胞内ての局在と密接に関連して発揮されると 考えられるが，肝組織を檴成する細胞内ての同アイン ザイムの局在につんての報告は乏しい。我々は所及び 肝病組織内における同醇素の免疫組織化学的及び電影 的研究を行古った。

対象と方法：ヒト及びウサギの正常肝，胎児肝，ヒ卜

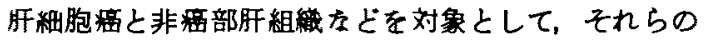
凍結切片を末固定のまま或はアセトン固定啳、モノク ローナル抗ウサギ媨由来 PKC抗体 (MBL社) を用い たPAP法にて染色した。免疫電㩆的観察恃，PLP固定 後，pre-embedding 法にて行方った。対照としてヒト 及びウサギの脳組裁す検討した。結果：ヒト及びゥサ キの正常肝組織怯抗PKC type I 抗体て㤌全〈染色さ れなかったが，抗 type II 捖体て sinusoidal I ining cell 加陽性反，抗 type III抗体古用々た場合恃胆管上 皮細胞のみが明かな陽性像を示した。成人及び成熟ウ サギの肝細胞ては抗 type III抗体て俥微去陽性像が示 唆されたのみであったが 胎览訮細胞で壮 linear pattern

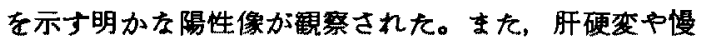

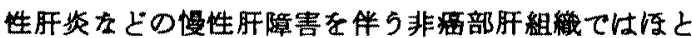
んどの症例で一部の肝細胞，とりわけその細胞膜側が 抗 type III抗体て陽性てあった。更に，肝細胞癌 7 例 中 5 例飞て訮絽細胞が抗 type 四抗体て明らか儿陽性 て，その程度恃陽性例 5 例中 3 例て非骠部慢性障害肝 組織内の肝細胞のそれ上り強加た。残り2例ては 程細胞恰性てあった。抗 type Iお上びII抗体て は肝細胞及び肝释細胞は全く染色され古かった。免疫 電顕的観察ては, 成人の正常肝細胞に陽性所見恃認奻 られなかったが，胆管上皮細胞におけるPKC type III

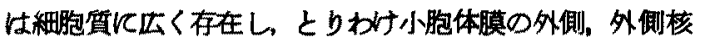
膜，ミトコンドリアの外膜，及び細胞質基質の部分、強い 陽性像を示していた。しかし，肝程細胞ては細胞質基 質内の P KC が減少し，小胞体膜：ミトコンドリア外膜， 核䐜側に接した部分に比教的多〈認められた。

考察：PKCの各アイソザイムが，肝組織内で明らかに 異右る局在を示すこと，ある種のアインザイムの発現

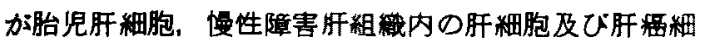
胞で増强していること，所裸細胞内て membrane associated PKC が増加しているてとなどは，肝病变 とPKCの発現との密接古関連を示焧していると判断 された。
398 肝悪性腄湯におりる Glutathione $\mathrm{S}$ - trans ferase アイソザイムの免疫組織化学的検討

佐藤 隆, 朝會一郎, 渡辺学, 佐伯日出貫, 杉本元信 （東邦大学第二内科）

伊藤金次 (同 第二病理学教室)

〔目的〕Glutathione S-transferase (以下 a S T)は 肝をはじめとして広く生体内に分布し，各種の内因性 および外因性異物と gluta thione之の抱合を触媒する解 畵塐素であると同時に, 各種有機陰イオンとの結合蛋 白(リガンディン)として知られている。てれまでに ラットおよびヒトでは多くのGSTーアイソザイムが分 踓され，種々の研究がなされてきた。今回われわれは， ヒト肝 GSTの塩基性アインザイムである GS T- $\mathrm{B}_{1} \mathrm{~B}_{2}$ ， および酸性アイソザイムで近年腫場マーカーとして注 目されているGST胞癌および胆管細胞癌患者について上記 G S T アイソ ザイムの訮内分布を，免疫組載化学的手法により検討 した。

〔万法〕当大学病院におりる剖検および開腹手術例の うち肝細胞癌 10 例，胆管細胞㿋 6例を対象とした。t ト所 GS Tの塩基性アイソザイムは $\mathrm{G} \mathrm{S} \mathrm{T} \mathrm{-} \mathrm{B}_{1} \mathrm{~B}_{2}$ を七 卜肝より精製し，家鬼に兔废し作製したヒト抗 GST-

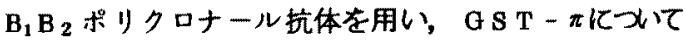
は, BIO PREP. (MEDLABS, LTD) のヒト抗

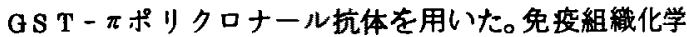
はPAP法およびA B C法により行い，染色性と病細 胞分化度とを対比検討した。

〔成績〕肝細胞笛では，， S T - $\mathrm{B}_{1} \mathrm{~B}_{2} ， \mathrm{OS} \mathrm{T}-\pi$ と

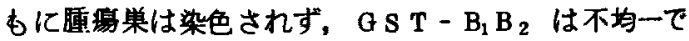
はあるが正常肝細胞に染色された。これに対しGST 几は胆管上皮細胞および偽胆管に染色される倾向があ り，また一部では再生結節の周辺部や腫瘍单近傍の肝

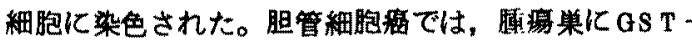
$\mathrm{B}_{1} \mathrm{~B}_{2}$ は染色されないか，GST- $\pi$ は 6例中 3 例に染

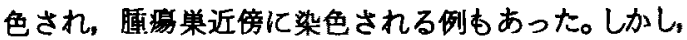
婳场細胞の分化度との相関は確認できなかった。

[結論] G S T - B B B $_{2}$ は正常肝細胞纪分布するか，肝

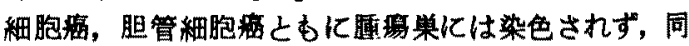
アイソザイムはこれら盾湯細胞中では隇少あるいは消 失する傾向が示唆された。乙れに対して，GSTー蛙 胆管系の細胞およひ胆管細胞癌で染色される例がある か，盾楊宩近傍の肝細胞や偽胆管に古染色されること から，腫場細胞の分化度よりもその細胞がおかれる状

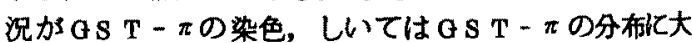
きく関わると考えられ，今後の研究課題之思われた。 
一肝硬変症との比較を中心として一

大部 諴”, 金子 聡, 高井智子、渡辺清治，奥平雅彦 ${ }^{2\rangle}$ (北里研究所メディカルセンター病理,") 北里大学医学部病理")

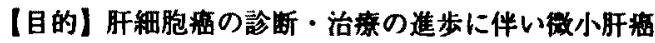
の穿刺吸引生検が行われる機会が增えてきた。これら の生模标本は高分化であることが多く、時として過形 成結節との籍別が困難なことも少なくない。そこで、 各種マーカーを用いた免疫組織化学的手法により旰虞 と過形成結節の相違を㛟討した。

【材料・方法】すへて外科的切除肝または贸状生検肝 を用いた。症例は、肝細胞㿋 (HCC) 16例、肝硬変症 (LC) 23例、著変のない肝組織 (NOR) 11例である。 各症と610\%ホルマリン固定・バラフィン包埋プロ ック標本を用いてAvidin-Biotin Complex (ABC) 法 により免疫染色を行っだ。使用した抗体は10種類であ ク、内訳は以下の通りである： $\alpha$-Fetoprotein (AFP) 、 Desmin, Fibronectin (FN) 、Ferritin、Transferrin、 Albumin, Keratin、Factor $\boldsymbol{W}$ 、 Carcinoembryonic antigen (CEA)、およびレクチンの一種であるUEA-I。

【成繶】 1. AFPはHCCのみに検出され（ 9 例 $/ 16$ 例、

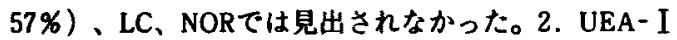
はHCCでは腫湯小血管および部分的に類洞壁に検出さ れた。一方、LC、NORでは門㹸枝、門㹸域毛細管およ $ひ$ 一部の中心静脈に検出された。これを実質内単位面 程あたりののUA-I 淂性小血管の出现頪度として比較 するとHCCの方が明らかに高かった3. DesminはHCC

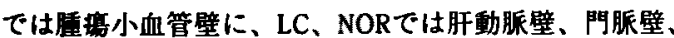
中心静脈壁に見出された。これを実質内Desmin陽性小 血管の出現頻度からみるとHCCの方が高かった。４FN はHCCでは類司壁に高頻度に見出された。5. Ferritin、 Transferrin、Albuminは、HCC、LC、NORのいずれの 実犋細胞内にも検出された。

【結語】HCC、LC、NORの 3 群間で10種類の抗体を用 いて免湥組織化学的に検索した。その結果、1)AFP淂 性綢胞の存在、2)UEA-I 陆性拈よU'Desmin隄性小血 管の出現頻度、3)FNの実算内分布においてHCCとLC の間で相違がみられた。これらの所見は穿刺吸引され た微小肝䆆組織の診断においても過形成結節病変との 路別をする上で頁献するものと思われる。
400 ヒトあるいはマウス畈細胞株に対する抗原 特異的マウス $\mathrm{T}$ ハイブリドーマ細胞による抗腫䌐作用 吉川正英，松村圭祐，石坂重昭，福井 博，过井 正 （奈良県立医科大学第 3 内科）

【目的】最近 B 細胞が抗原提示細胞としての作用をも ち、B細胞上の抗体レセブターを介して特異抗原をる わめて効年よくへルパーT ( Th ) 細胞偍示できるとと が明かとなった。我々はとのようにして活性化された $\mathrm{Th}$ 細胞の稩胞障害活性を倹討し，ヒトあるいはマウス の肝盾細胞株に対してb，Th 細胞が細胞障害活性を示 すととを確認したので，との新たな抗腫蝊作用につい て埌告する。【材料と方法】抗原提示細胞としてマウ スBリン八舼株A 20-2 J (H-2d)，およびA20-2 Jを親 株としてTNP特異的な sI gMtnp をコードする遺层子を合

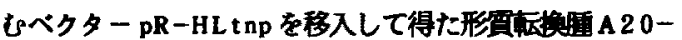
HL を用いた。 Th 細胞として ovalbumin (OVA 特異的な マウス3D0548ハイブリドーマ紐胞 (1-Ad ristricted) を用いた。Bystander cell として。,ヒト肝密細胞侏 Alexander 細胞, マウス肝癌細胞株 TIB-75, Daudi 細胞。 K562 細胞, NK resistant として知られるマウス mastocytama P-815 などを用いた。抗原提示作用は活性化 Th細胞より库生される。IL-2 を指摽とし，細胸障害活生 は ${ }^{51} \mathrm{Cr}$ release assay 亿より既定した。また、肝程細胞林 の細胞障害性については，培美上清中のトランスア ナーゼも测定し検討した。【結果】A20-HLは外来性 て移入されたイデオタイブを表出しており，親株A20 $-2 \mathrm{~J}$ より約 $10^{8}$ 倍低いTNP-OVA 湍度で Th 細胞 3DO 548 亿抗原提示ができた。との際，Th細胞は，抗原提 示細胞に対してだけでなく, bystander cellとして加え られた肝䅹細胞株 Alexander 細胞, TIB-75 細胞に対し ても細胞障害性を示した。この Th 細胞の有する細胞障 害世は，抗原提示細胞としてA 20-HL を用いると親株 A20-2J を用いるより約 10`倍低いTNP-OVA 湌度加 ら認められ，效果的に旰暴細胞を般し得た。K562 細胞. Daudi 紐胞, mastocyt oma 株 P 815に対しても 細胞障害活生は認められた。この $\mathrm{h}$ 細胞の活生化現象 は、抗クラスI抗体，抗イデオタイブ抗体により抑制

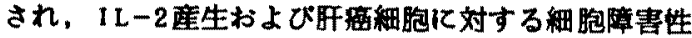
は阻止された。抗原提示細胞による抗原の up-take， degradation の過程をモネンシン，ロイペブチン， TPCK などでブロックすることでる Th 細畇の活性化 は阻止されたが、とのようは燕用の存在下でも OVA ペプタイドは Th細胞を活性化し得た。【結論】抗原 特異的 Th細胞が活性化された際。非特異的にヒトある いはマウス肝䠛細胞侏付対しても細胞障害性を有する ととが観察された。 
401 肝瘱細胞膜抗原にたいするモノクローナル 抗体の作成之，その特性の解析

古川哲也、山崎隆弘, 黒川典枝, 安永满, 小西知己, 福本陽平, 沖田 極!" 福本折夫 ${ }^{2)}$

("山口大学第一内科)，(同解剖学第一数室）

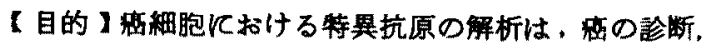
治療また，その病態を解明していく上で重要な問題て ある。我々はとト肝舟細胞侏 (HuH－7)を抗原として 用い，モノクローナル抗体の作成をおこない，禹特異 あるいは鬼関連抗原の検出を試みた。

【方法】HuH-7をBalb/c マゥスの尾軤脈より投与 し感作を括こなった。腪よりえられたリンバ球をN $\mathrm{s}$

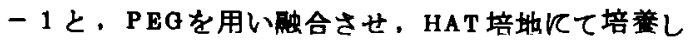
た。抗体の検弥は A B C 法，R I A 亿て行い，クロー二 ングは限界希㹞法を用いた。AMERSHAM社の Mouse monoctonal antibody isotyping kit $\mathrm{K} \tau$. 得 $5 れ た$ 抗体のsub class を决定し，手術等で得られた肝細胞

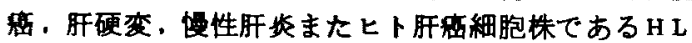
E，H L F と各抗体との反反性を A B C 法で調へた。次 K、 HuHー7を細胞分画にわけ，モノクローナ几抗体 が反応する抗原が存在すると考えられる分画を用い， Western blotting を行い，抗原の分子量の决定を試 みた。

【成績】HuH－7と反応性を有するモノクローナル抗 体は，その染色性から細胞質内に抗原が存在すると思 われる clone - 1，6 と膜抗原を認識していると考えら れるclone-3，8の4種類であった。このうちclone -1，3，6は，検索したすべての非肝鬼細胞との反传 を有し、正常抗原をす認識しているものと考えられた。 clone - 8は HuH-7 の膜抗原を認識していると思われ る抗体で、非肝船組織との反综性が見られたのは一部 であり，かつ得られた HCC 標本の約半数と反応したた め，何らかの成透抗原を認識している可能性がある と考えられた。clone $-8 の$ sub classは I g

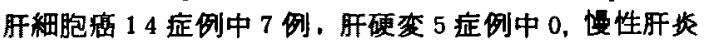
2 症例中 1 例，またヒト腰細胞 H L F Vたいし反店 性を有していた。

【結論】ヒト肝細胞株HuH-7 亿対するモノクローナ 几抗体を作成し，4種類の抗体を得，そのうちのひと つが認識するものは禹関遧抗原とおすわれ，抗体打よ び抗原についての解析を行った。
402 七ト肝馧細胞株(PLC/PRF／5)関連抗原を 認識するモノクローナル抗体KS-HP7に奶するモノク口 一ナル抗イディオタイプ抗体の作製とその応用 小野良策，小出典男，坂口孝作，武南達郎，松島 蒠 高畠弘行，佐々木儌辅，过 孝夫

（岡山大学第一内科）

【目的】癌免疫における抗イディオタイブ抗体の関与 を in vitroで検討するためには安定した再現性のおる システムとしてモノクローナル抗体を作製するととが 有用であると考えられる。我々は16.5 kd のヒト肝祸緗 胞株(PLC/PRF／5)関連抗原を認識するモノクローナ ル抗体KS-HP7に対しモノクローナル抗イディオタイ プ抗体 $(\mathrm{MoAb} 2)$ を作製しその応用を試みたのて郝告す 万。

【方法】精製 KS-HP7をグルタールアルデヒド存在下 でKLHと重合させ，マウス腹腔内へFreundのアシュバ ントと共に免疫した。このマウス脾細胞とマウスミエ ローマ細胞 Ag8-6.5.3との間で細胞融合を行なった。 MoAb2のスクリーニングは，固相化KS - HP 7 に結合 したMoAb2をペルオキシダーゼ標識 KS - HP7で検出 するサンドイッチアッセイにより行なった。

【成績】No.7,11,18,21,218の5種類のMoAb2を得た。 これらはいずれもKS -HP7の標的細胞への結合を港 度依存性に阻止した。KS-HP7を含めて45種類の様々 な特異性、フイソタイプの固相化モノクローナル抗体 への反応性をみると、いずれのMoAb 2 も免废に用い たKS-HP7にしか反応しなかった。Western Blotting による検討では.No.21は非迕元KS-HP7としか反応し ないのに対し，残りの 4 つは還元したKS-HP7のL鎖 とも反応した。cross blocking assayではNo.21は自分 自身でのみ標識抗体の結合が阻止されたか，残りの 4 つは互いに結合を阻止した。さらにとの 4 つは結合阻 止曲線の50\% inhibition 值より二群に分類でた。№. $21 の$ MoAb2 を用いて競合的結合阻止反応により cell lyzate 中のKS -HP 7 誈撞抗原の定量が可能であった。 【結論】KS - HP 7 に対し 5 種類のモノクローナル抗 イディオタイプ抗体を作製した。各MoAb2はKS-HP7 上の抗原結合部位近傍の privateなイディオトープを琶 識しているものと考えられた。No.21はH，L雨鎖で形 成される三次元的イディオトープを認識しているのに 対し残りの 4 つは L鎖上の一次棈造に依存したイディ オトープを認識していた。イディオトープの配置は cross blocking assay の結果から空間的に三群に分類 できた。No.21は KS-HP7認境抗原と三次元的に近 い橉造を有している可能性がり，競合的結合阻止反 応により癌抗原検出アッセ1系か組める可能性が示暖 された。 


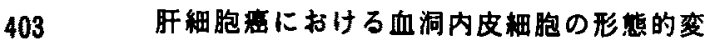

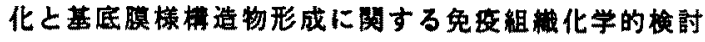

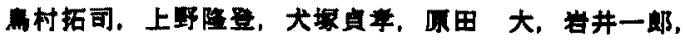

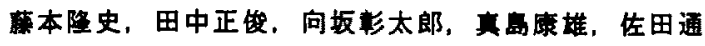
夫, 谷川久一

$$
\text { (久留米大学第二内科) }
$$

【目的】我々は吸引生検て璪取された肝細胞蛙組織を 用いた検討で基底膜様棈造物 (BM) か内皮細胞基底側や 䀒豦䚀胞血洞側などに局在することを報告してきた。 今回は、肝湅胞悹の血洞内皮細盷の形㤰的変化と内皮 細胞基底側のBM形成に成し、免度組織化学を含めた検 討を行ない舆味ある知見を得たので報告する。

【対象と方法】対象は肝細胞基37例（男性30例，女性 7 例，年令 42〜80才)。方法は吸引生検で得た肝細胞

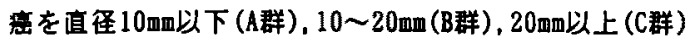
に分け、10\%ホルマリン固定肝我組織をHE染色し、各

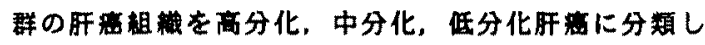
た。さらに一次抗体に抗IV型コラーゲン (Ty. IV) 抗体， 抗ラミニン (La) 抗体を用い醉菜抗体法による親察を行 ないほぼすへての血洞に洽って一次抗体との反座物 の局在を認める組織を(十),一部に局在を認める組織を (土)，ほとんど局在のみられない組維を(-)とした。ま たPLP 固定肝湶組織に同様の抗体を用い醉案抗体法に

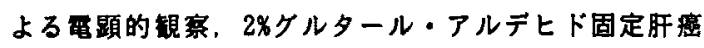
組織を用い通常㫣顕による钼察を行なった。

【桔果】光顯) 醇㐘抗体法；Ty. IVはABC 群のすへての

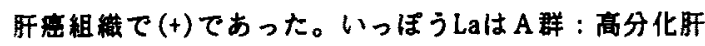

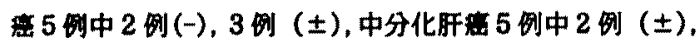

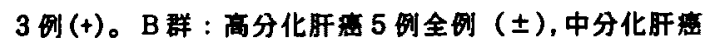
7 例中 3 例 $( \pm) ， 4$ 例 $(+) 。 C$ 群: 高分化肝茈 2 例共 $(+)$ ， 中分化肝癌の 9 例中 1 例 $( \pm), 8$ 例 $(+)$ ，低分化䏦瘦 4

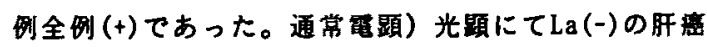
組維では血洞の subendothelial space (subendo.)に維 な線維状棈造物は認められたがB留はほとんど䅐察され

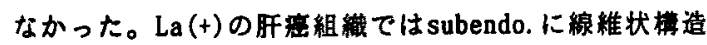
物の增加を認め、内皮細胞基底㑡に沿ってBMか局在し ていた。また低分化な肝密ほど内皮細胞のfenestraeが 減少する倾向にあった。免段電影）内皮細胞の粗面小 胞体に一致してTy. IVやLaの局在を照めた。

【結諗】1)肝藻の血洞 subendo.には早期よりTy. N が存在し、そこに内皮細胞よりしaが分汹され内皮湅胞 基底側のB俄形成されることが示鲐された。2）低分 化な肝密ほど早期よりBMの形成が始まると考えられた。 3）血洞内皮細胞の fenestraeは禹分化肝我に比へ低 分化肝症で減少する煩向におった。4)肝盘血洞にお けるBM形成や内皮絧胞の形態的变化には subendo.に增 加した線維状構造物の関与が示豀された。
肉腫様变化を伴った胆管細胞瘦の免度組蟣学 的研究

前田直人 (六日市病院内科) 、堀江 裕、岸本洋輔、 川崎宽中（鳥取大学第二内科）

[目的]病理組織学的に癌嗹が肉軼梾变化を伴 $5 こ と$

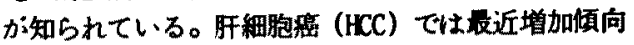
にあるとされるがその成因は尚不明である。一方胆管 細胞癌 $(C C)$ での肉腫様变化についての埌告は見当た らない。今回われわれいてCで肉盾様形態を伴った 症例を释䂆したのでその兔度組織学的染色を詳細に宁

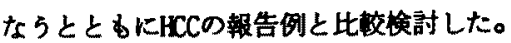

[対象㧍上び方法] 対象恃本学内科お上び病理学教公 で1977年から1989年までの13年間に剖検した肝腫焉 140 例中13例のCCで、そのうちに肉盾様变化をみとめた2

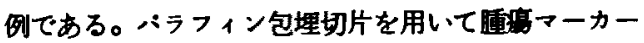
としてAFP、CEA、DUPAN-Iを、上皮性マーカーとして EMA、Cytokeratin (PPK1およひCAM5.2) を、非上皮性 マーカーとしてVimentinをそれぞれABC法て染色し、 强陽性 $(+)$ 、陽性 $(+)$ 、弱晹性 $( \pm)$ 、陰性 $(-)$ の4段階に染色した。染色部位はCC部分、肉腫様変化 部分、移行部、正常胆管上皮部分を染分分けた。

[結果拉よび考案］图1に应例1の結果をまとめた。腫 㻛マーカーは畽场部ではCEAの之強陽性に染まり、肉 睡部分と移行部では染色されず、AFP、DUPAN-【はいい ずれも陰性であった。上皮性マーカーはCytokerat in ではCC部に強陽珄であったが肉腫様部位およひ移行部 では陰性であった。非上皮性マーカーは、肉厙部位お。 よび移行部では虫陽性に染まり、CC部では陰性であっ た。

癌盾の肉隀様变化は區床病理学的に注目されている が、HCCで士従来の報告で壮汪とんどの例で移行部お 上び肉腫部位で上皮性マーカーが陽性でありHCCがら のtransformationとする説が有力である。今回われか れの成绩からみるとCの部分が上皮性に染色されたる のの、移行部および肉稙様变化の部分は上皮性のマー カーでは全く染色されナ間葉系マーカーであるVimentinの々に强く染色された。この成鈢はHCCの如く癌揰 の部分が﨔純にtransformationしたとは考え難く本例 をchol angiosarcomaとナべれかるしくは完全に内腫 様の性格に变化したすのと考えられた。

\begin{tabular}{lcccc} 
& \multicolumn{3}{l}{ Tumor cell } \\
\cline { 2 - 4 } & CCC & Tran. & Sar. NE \\
\hline CEA & ++ & - & - & + \\
AFP & - & - & - & - \\
DUPAN-II & - & - & - & + \\
Reratin(PPKI) & ++ & - & - & ++ \\
EMA (CAM5.2) & + & - & - & + \\
Vimentin & + & - & - & +- \\
\hline
\end{tabular}


405 肝練胞癌症例における H C V抗体の娭討

林 星舟，佐伯传一，近藤朝明，田中 武，柴山隆男， 大竹寞雄，田中 慧，服部 信，岡本道世"，小记直宏"， 高本 滋, 吉原なみ子

(東京都立駒込病院肝䑏内科, 同 渝血科",

国立予防衛生研究所 エイズ研究センター ${ }^{* *}$ )

【目的】肝細胞癌と肝炎ウイルスとの関連を明かにす る目的で, 肝細胞癌症例における H C V 抗体 ( C 100 抗体，カイロン社 ) 陽性率について娭討しだ。 【対象と方法】当院にて释検した肝紐胞癌症例 359例 中, 肝障害発現後に輸血を受けていない241例を対象 とし，穴背景因子（HBVキャリア（B：s抗原陽 性または c 抗体高抗体価) か否か。血歴（ T：肝障 害発現 8 年以前) の有無, 飭酒歴 ( A : 3 合/日以上 5 年以上)の有無ににより5群に分類した。 H C V抗

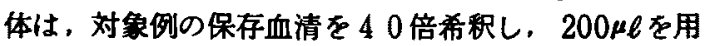
いてビーズによるEＩA法（アボット社キット）にて 同一キットて一括測定した。

\section{【成制 】}

1）各群の H C V抗体陽性率は下記のごとくであり， 男女間にH C V 抗体陽性率の盖はなかった。

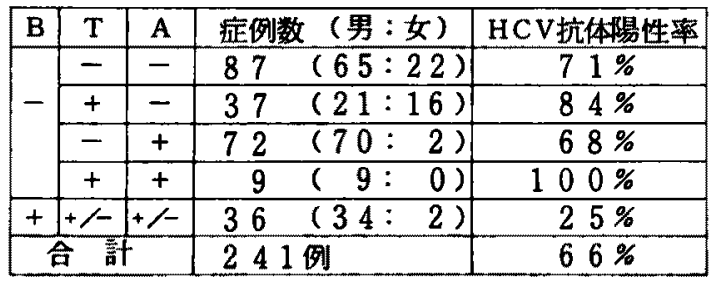

2) H C V陽性例のうち, $\mathrm{B} \ominus \mathrm{T} \ominus \mathrm{A} \ominus$ 群と $\mathrm{B} \ominus \mathrm{T} \oplus$ $\mathrm{A} \ominus$ 群とては肝癌発見年龄の分布に差は認められず。 また放酒が加わるとそれぞれ平均年龄が 5 年程度早く なった。

3) 年龄別にH C V抗体陽性率を見ると，39才以下

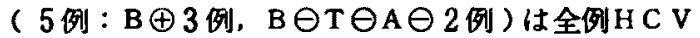
抗体陰性であったか，40才代は $58 \% ， 50$ 才代 $71 \% ， 60$ 才代 $65 \%$ ，71才以上は $68 \%$ 才市っ た。

4) $\mathrm{B} \ominus \mathrm{T} \ominus \mathrm{A} \oplus$ 群のうち，臨床的に肝障害の原因 がアルコールと考えられた 14 例のうち7例( $50 \%$ ) はH C V抗体陽性であった。

【結語】1) H C V抗体陽性例のうち輪血歴の有る症 例と無い症例とては肝癌発見年龄に差はなかったが， 领酒歴の有る症例は無い症例に比へ，発見年龄力゙約 5 年若かった。2) 肝細胞嵒拝例のうち，若年層（３9 才以下)ては 4 割が非 H B Vキャリフて，全例H C V 抗体陰性であった。若年発生肝細胞癌症例においては H CVの関与が否定的でった。
406 肝細胞癌に出現するマロリ体の意義：フ* イルゲンーD A 顕徽蛍光測光法に上る検討 細 正博, 中沼 安二 (金讯大学第二病理)

【目的】マロリ体は肝細胞内に出現する特異な硝子体 である。近年、肝細胞癌（肝虏）にもマロリ体の出現 することが知られ、䀒痤細胞が示す速伝形質である可 能性が示唆されているが、証拠に乏しい。今回、この 可能性を検討するため、マロリ体陽性肝盘の核DNA 量を測定し、ブロイディパターンを求めた。

【方法】対象は1972年から1987年の間に、本学で剖换

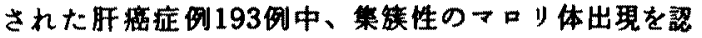
めた20例（同時にマロリ体陰性肝癌部。存在）と、マ ロリ体をまったく認めない肝癌11例。ホルマリン固 定、ヘラフィン包理ブロックより、厚さ5 5 と $12 \mu$ の 連繶切片を作成し、 $5 \mu$ 切片には型の如くHE染色、 12 $\mu$ 切片には、フォイルダン染色を施し、5 5 の HE集本 にて組維像を確認しながら、肝癌細胞内の核DNA 量 を䫒微蛍光測光法により定量した。測定に当たって は、マロリ体陽性部分の肝癌細胞と同陰性部分の肝虚 練胞をそれぞれ测定し、核DNAヒストタラムを作彗 して比较検討した。対照として、正常剖検肝9例と、 マロリ体陽性肝癌例の非峦部硬变部の湘定值を用い た。切片中のリンバ球を50個测定し、そのDNA 贵の 影频值を2Cの值とした。

【成制】正常肝と肝硬变の肝細胞のDNAヒストクラ ムは、2C 付近に强いビークを持ち、少数の $4 \mathrm{C}$ 付近の 核が見られる、ディプロイドバーンを示した。マロ リ体䧔性肝癌例と、マロリ体陽性肝癌例のマロリ体陰 性肝癌部分の肝盘細胞は、ディフロイトハターンか ら、2Cの倍数体が多く出現するハイハーーフロイド ターン、さらに2Cの倍数体からはずれたDNA 基の核 が多く出現するフニニブロイドハターンまで、多彩な DNA ヒストクラムハターンを示した。一方、マロリ 体陽性部分の訮虚細胞は、すべてハイハーフフロトハ ターン、アニニフロイドハターンを示し、ディプロ1 ドンターンを示したしのはなかった。また、マロリ体

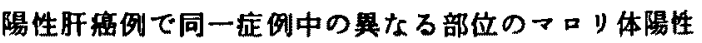
部分の肝癌細胞の核DNA 严を7例について测定したと ころ、6例で同一のDNA ヒストグラムパターン (ハ1 ヘープロイドターン3侧、フニニブロイド・ターン 3 例)を示した。

【結諭】マロリ体陽性肝癌のDNAヒストグラムには ハイヘープロイド化、フニニプロイド化が共通してみ られた。主た、同一症例のマロリ体陽性肝癌は、部位 が異なっても同一のヒストクラムを示していた。以上 より、マロリ体形成は肝磨が示す1つの迹后形算であ る可能性が示唆された。 
407 症肝炎における末梢血活珄化Cytotoxic

T細胞の経時的な変動について

大能菒子、一瀬裕子、佐较佳浩、黒田聖仁、高木 徹、

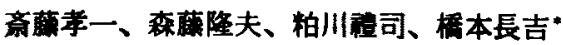

（福島県立医科大学第二内科、同 輸血部*）

[目的］愠性活動性肝炎では、肝組織内人の漫潤細胞 の大多数がCytotoxic T細胸であるといわれており、 また、末梢血中では、肝炎の寛解增要、抗体の出現な どによりリンパ球サブセットの娌きが変化することが いわれていろ。一方、症肝资の病態には免疫禎合体 などの波性因子の阅与とともに細胞性免投能の異常も 示暖されているか、経時的なりンパ球サブセットを検 討した報告は少ない。

今回我々は、唯肝炎患者の末梢血リンパ球サブセ ット、とくにLeu 2a'15 細胞 (Cytotoxic $\mathrm{T}$ 細胞) について、経時的な测定を行い、䠦床像と対比検討し たので報告する。

[万法]平成元年より楅島県立医科大学第 2 内科で経 铁した、犬山シンポジウムの診断基準を満たした舦症 肝炎を生存例、死亡例にわけ梌討し、対炤として急性 肝炎别について模討した。

リンバ球サブセットは、ヘバリン加末梢血を比重遠 心法で単枝球に分離L、FIＴＣ及びPE標識のモノ クロナール抗体を用いたtwo-color flow cytometory 法て、FAC scan にて测定した

[結果］症肝炎の末梢血リンバ球サブセットは、ほ とんどが急性期に急性肝资と比校してLeu 2a+15 細 胞Leu 2a' H L A-DR* 絴胞 (活性化Cytotoxic T 湅胞）比率の著明な上昇が認められた。生存例では、 Leu 2a' 15 細胞の比率は正常あるいは軽度上昇して いろのみであったが、Leu $2 a^{*}$ H L A - D R+ 細胞比 率は上昇していた。経時的な㛟討では、治嵲とともに リンパ球サブセットの此格は正常化した。また、血数 交換意法を施行した症国では、活性化Cytotoxic T 細 胞の著明な低下がられた。

急生肝炎では、急性期、回復期において、リンパ球 サプセットに大きな葆化は認るられなかった。

[蛣詥] 症肝炎では、急性期のリンパ球サブセット の変化、とくにLeu $2 \mathrm{a}^{\prime} 15$ 練胞、Leu $2 \mathrm{a}^{+}$H L A $\mathrm{DR}^{+}$細胞の比率の予役との琏連が示㖅された。また、

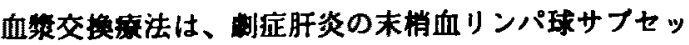
トに影を与えると考えられた。
408 症肝炎におけ具中可浩生IL2 receptorの 测定とその䀲床的意绕について

安藤量基，白鳥義宗，越野淂介，村上额婎，杉原潤一， 大西弘生，森脇久隆，武藤泰敏

（蚾卓大学第一内科）

【目的】近年，血中可溶生 IL 2 receptor (sIL2R)が 僈性肝炎の活缜性と一致して変勒するとみなされてい ろが，问㱏肝炎についての報告はない。今回刻症訮炎 (FH)を中心に sIL 2Rの検討を行い，释過中の変動と 予後について検討した。

【対象·方法】健常人(Normal) 5例，急性肝炎(AH) 5

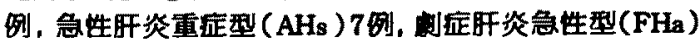
7 例，应肝炎亜急性型(FHs) 3 例の計 27 例を対象と した。 $\mathrm{AH}, \mathrm{AHs}$ は入院時末治療の検体を使用し，FHは 入院時以阵経過を追って测定した。検体は -20 ○以下 で保存したものを使用し，血中 sIL 2 Rの测定をT cell Science 社製 ELISAキットを用いて行っだ。なお，䀒 不全死以外の死亡例は除き，またはは同様な治癔法が行 われた FH应例について経時的変功を舅宗した。また， ステロイドホルモンの使用列は除外していろ。

【成績】血中 sIL 2 R 湍度はNormal；704.5 $182.9 \mathrm{U} /$ $\mathrm{ml}($ mean $+\mathrm{SD}), \mathrm{AH} ; 2106.4 \pm 636.2 \mathrm{U} / \mathrm{ml}$, AHs ; 3409.2 $\pm 3012.9 \mathrm{U} / \mathrm{ml}, \mathrm{FH}$ 全体では $2953.2 \pm 1398.9 \mathrm{U} / \mathrm{ml}$ で

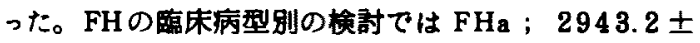
1313.2 U/ml. FHs ; 3429.2士1218.2 U/mlであった。経過 中の最大值をみると，FH全体で 3089.1 土1313.1U/ml であり，病型別では FHa ; $2947.2 \pm 1313.1 \mathrm{U} / \mathrm{ml}$. FHs ; $3429.2 \pm 1218.1 \mathrm{U} / \mathrm{ml}$ であった。Normal 亿対しAHでPく 0.001 , AHs で $P<0.05$, FH全体で $P<0.005$ の有意な上 昇を示した。また各肝疾患内での比校では，AHに対し FHsで有意な上昇を示した $(P<0.05)$ 。FHの中で生存 例と死亡例に分けると，入院時で生存例; $1535.5 \pm 811.3$ $\mathrm{U} / \mathrm{ml}$, 死亡列； $3110.3 \pm 1159.3 \mathrm{U} / \mathrm{ml}$ ，取大值では生存例

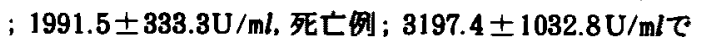
あり，何れも死亡例で有恚な上昇を示した $(P<0.05) 。$

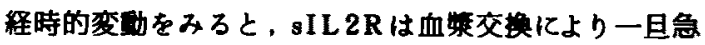
速な低下を示すが，2000U/mi以上へ再上昇するものは 全例死亡していた。

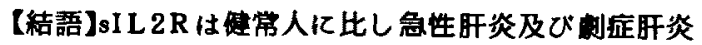
ではいずれも有意な上昇を示し，䀘におけろ炎症反応を 反映しているとの仮貺を支持していろ。特にFHsでは 通常の急性肝炎に対して有意に上昇し，またFH死亡例 では生存闭に比べ有意に高く，予错の推定に有用であ った。さらに，8IL2RはIL2の作用を抑制し次正を持 続させろという実跧成綨からみると，FHsで有意な上 昇を示したととは，再然を練り返しながら要化してい くという FHs の特異な病䑨を解明する上で重要な知見 と言えよう。 
409 䀒炎酒症化の免度異常に関す万研究一特に末 梢血及び肝内リンパ球重分画とIL2 添加の影警につ い。

安藤量基，前田胃男，杉山宏，刘沛，山田铁也， 大西弘生，森脇久隆，武藤泰敏 (吱阜大学第一内科) 竹村正男 (同 中央検查部)，野間昭夫（同 臨床模 㚗医学)

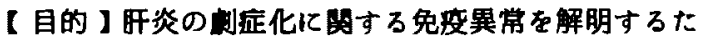

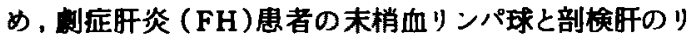
ンパ球严分画を検討した。さらにFH血清およびIL2添 加の影策を正常人リンパ球の培盖系を用いて検討した。

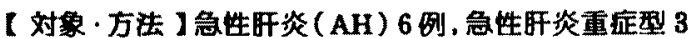
例，讧症䀒炎急性型 (FHa) 4 列と亜急生型 (FHs) 1 例 の計 14 例を対象とし、いずれる入院時の単核球を用い た。末梢血リンパ球は比重逗心を用い，旰内リンパ球

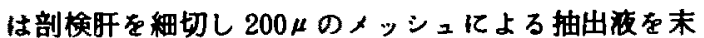
梢血と同粎に処理しだ。とれらを各種抗体を組み合わ せ二重染色を行いFACSを用いて分析した。正常人リ ンパ球の培美系は，O型の践常人上り得られた単核球 を $1 \times 10^{6}$ 個 $/ \mathrm{m} l$ 亿調整し，正常人AB血清を対照とし FH患者血清を $10 \%$ 亿るように添加 $(100 \mu l / \mathrm{m} l)$ し， rIL2 $(1000 \mathrm{U} / \mathrm{m} l)$ の添加の有無により, AB 血清添加群 （a ）, FH 血清添加群（b ），AB 血清+ IL 2 添加群( c ), FH思者血清 + IL2 添加群 (d)の 4 群の培盖系正作製. 72 時間培美後 CD8，CD11 抗体そ用いて解析しだ。 【成績】末梢血リンパ球の解析では，CD 8*CD 11*分 画( suppressor $\mathrm{T}$ cell; Ts) はAH ; $12.36 \pm 2.65 \%$ (mean $\pm \mathrm{SD}$ ), $\mathrm{FH} ; 6.32 \pm 3.86 \%, \mathrm{CD} 4+2 \mathrm{H}^{-}$, $\mathrm{CD4}^{*} 2 \mathrm{H}^{*}$ ( (helper-inducer- $\mathrm{T}$ cell/suppressor inducer $\mathrm{T}$ cell $; \mathrm{Thi} / \mathrm{Tsi})$ は $\mathrm{AH} ; 1.77 \pm 0.81, \mathrm{FH}$; $0.76 \pm 0.48$ で何れも FHで有意な $(P<0.05)$ 低下を示 した。一方旰内リンパ球ではCD4/CD8 は低下し， CD8 陧生細盷の内 $70 \%$ 上が HLA-DR 陌生であっ た。In vitroの培盖系では上記 4 群間で比校したと C3, CD 8* CD 11*分面住(a)飞対し(b) $(P<0.05),(c)$ て対し(d) $(P<0.005) て ゙$ 有意に低下した。また，IL2 の添加により(b)に対し(d)で有意に( $P<0.0001)$ 上异した。

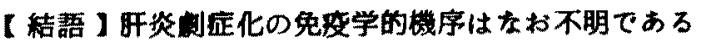
かi，Ts の低下と旰内 cytotoxic T cell (Tc) の集稙加 特数的所見と考えられている。しかし，どのようを血 中因子がこの異常に関与するか虫末解決である。今回， FH䒅者血清が正常人血中Ts 同時添加によって解除されるとの成績が得られた。さ らに，演者らはFH患者の血中に soluble IL2 receptor が増加するとの成績得ていろので，FH患者血 清に存在する IL 2 blocking factor が重要な役割 を演しているてとが強く示唆された。
410

けろロイコトリエン $B_{4}$ 痤生能と血清 PAF の梌討

浅野文祐（国立療意所鮍皋病院）

森脇久隆，白鳥義宗，越野淂介，村上啓雄，杉原型一， 大西弘生、武藤泰故（吱皁大学第一内科）

【目的 J近年、䀒炎缡症化に際し、アラキドン酸カスケ ードとくに5-lipoxygenage pathwayの六進が潹く関与 するととが示陖されており，すでに我々は急性䀒不全 モデルで PBMCの LTB，産生能が元隻し，盰内マク ロファーシのそれをよく反映している事を報告した。 一方，PAF は炎应時の白血球の活性化阔与しアラキ ドン酸代謝座物と聚密每成保があると考えられている。

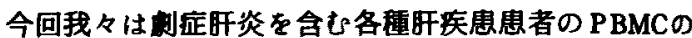
$\mathrm{LTB}_{4}$ 産生能について検討するとともに血清 PAF值と の関連についてる検討した。

【方法 了划症䀒炎 10 例，その他の䀒疾患 14 例（急生

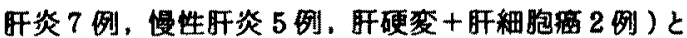
健常者 6 例を対象とした。末梢血より Ficoll-Conray 比重遠心法によってPBMCを分離し， $1 \times 10^{6}$ 個に調 整のうえ $37 \mathrm{C} ， 15$ 分間 preincubate，さ $5 に C \mathrm{Ca}$ - ionophore $(2 \mu \mathrm{M})$ 添加し 5 分間培意，その前後の培美花中LTB 度をHPLCに上って测定し，LTB座生能を算出した。 また劇症旰炎思者们いては経過を追ってLTB 能を検討すると共に血清PAF も测定した。PAFは探 血直後化 3 倍量の命メタノールを加え遠沈し、上清を gas chromatographic-negative - ion chemical ionizationmass spectrometric ( GC-NICI-MS) method $\pi$ よ り剧定した。

（成績 】1）PBMCの $\mathrm{LTB}_{4}$ 座生能：副店肝炎患者の 入院時にはPBMCにおけるLTB、座生が 10 例中 9 例 亿椧出され平均 $3.4 \pm 1.0 \mathrm{ng} / 10^{6} \mathrm{cells} / 5 \mathrm{~min}$ であった。

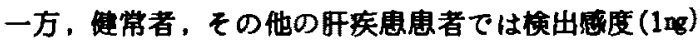

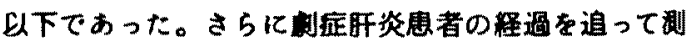
定した場合，入院時に高值であったPBMCのLTB 生能が臨床経過に先行，おろいは並行して低下する㑯

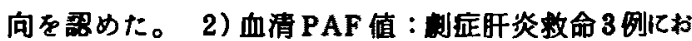
いて則定した血清 PAF は mean 29. 2 (range 24.4 -33.6)

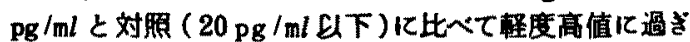
ずしかも LTB、とは異なり経過中特に変動を認める かった。

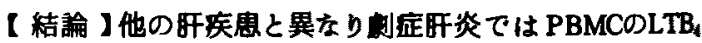
産生能 1 つの指標とする 5-lipoxygenage pathway

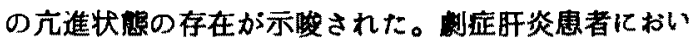
ては， $\mathrm{LTB}_{4}$ 座生能は特沉発后早期に允進するとと， さらに臨床経過をよく反映して推移することが覞察さ れた。一方，今回䤃察しえた時間的経過内では血清 PAF 值は著明な上异や特異的な変動がなかった。帡っ て PBMCのLTB 4 座生能は血清 PAFに比して制应旰炎の 病勢の一つのマーカーとして有用であると考えられた。 
411 症肝炎における肝組轼内 tumor necrosis factor 謁性細胞の免組樴学的検討

山田鉄也，安藤量基，刘沛，村上啓雄，杉原堽一， 大西弘生，森脇久隆，武藤泰敏 (汥阜大学第一内科)， 高見 刚，尾島昭次 (同第二病理)

【目的】我々は㓺应旰炎 (FH) 艒者末梢血単核球の LPS 刺浅下での tumor necrosis factor (TNF) 座生能 が急生旰炎に比し，有意に立進していることから，TNF がFHの発症機序に深く関与していることを報告してき た。今回我々はFH舫者の肝組機内における TNF陽性 細胞を免度組織化学的に検討したので報告する。

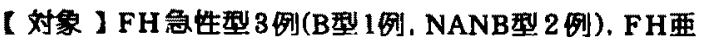
急生型 3 例(A型 1例, NANB型 2 例). "Acute-on-Chronic"

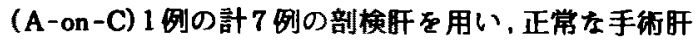
及び剖検旰 2 例と他の旰疾患 3 例（LCの手街䀘と剖模 旰各 1 例、ルポイド旰炎の手術旰1例)とを比效した。

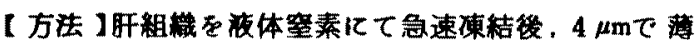
切。命アセ卜凋定 ( $4^{\circ} \mathrm{C} .10$ 分)し。抗 TNF- $a$ モ/クロ 一ナル抗体(旭化成より共与, V $3 \mathrm{E} 5,100 \mu \mathrm{g} / \mathrm{ml}$ ) 有 いてABC法てて免废租織染色在厅った。2次抗体はビオ チン化ヤギ抗マウス免度グロブリン(DAKO社, $50 \mu q / \mathrm{m} l$ ), $A B C$ complexは Vectastain $A B C \neq ッ ト$ (Vector 社)を 用いてDABにて発色させた。そして，単位面積当たり のTNF- $a$ 陧性稩胞数（個/助）を求めた。

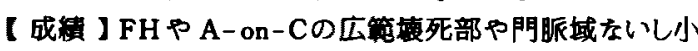

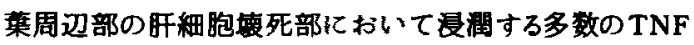

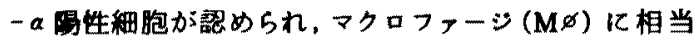

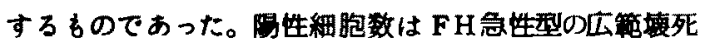
部では，B型で 216.3，NANB 型で各 253.8，275.0

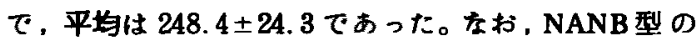
1 例では䀒細胞残存部がみられ，残存部門眽域の陽性 細盷數は 41.3 でおった。FH 重急性型ではNANB型

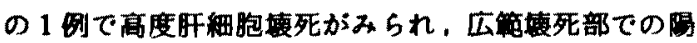
生細盷數は 368.8 ，残存部門眽域では 86.3 であった。 他の 2 例は䀒細胞褯死が軽度で全切片中数個の陽性細 盷を琶めろのみであった。なお，A-onーCでも広管液 死部で 167.5 、残存部門眽域で 107.5 であったのに対 し、対照例には淂性細盷は全くみられなかった。

【結論】TNF- $a$ 隄生細胞はMøに相当し. 細胞数は复 死の程度と関連していた。FHPA-on-Cでは広籍度 死部に陽生練胞が多数浸間し，牫存部のみられろ应例 では残存部門脈域の晹性細胞は厇籍萄死部に比し，少

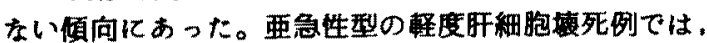

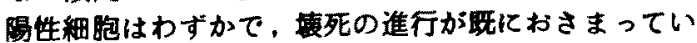
るためと考えられた。以上より肝局所におけるMøの TNF- $a$ 産生が润症所炎の発应に深く関与し，特に度 死の活発な時期でその傾向が强いととが強く示唆され た。

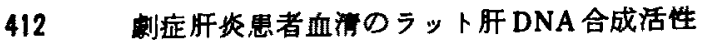
抑制一in vivoおよび in vitroにおける検村 山田春木, 戸田剛太郎, 檑本直明, 池田有成, 吉川雄 二, 光井洋，黒川 清。岡 博*, R.Williams** (東京大学第一内科, 東京繁祭病院*，King's Col lege Hospital ${ }^{* *}$ )

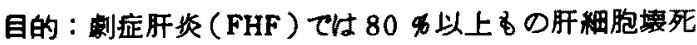

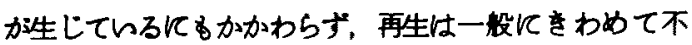
良てある。我々は第23回本学会総会において, FHFの 际著增する，患者血清の分子量 1 万以下の中，低分子額 域に，70 部分肝切除 $(\mathrm{Hx})$ ラットの肝DNA 合成を抑制 する活性が出現しているととを報告した。従来，血小板 成分、肝細胞膜成分，FHF患者血清のアルブミン結合物 犋等に上る初代培盖肝細胞DNA合成抑制の報告はある が、血清のこの分画 $(M W<1$ 万)には抑制活性は無らと されていた。今回，初代培漛肝細胞を用い，乙の分画に わ強的DA 合成抑制活性を認めたのて報告する。 方法：(1) in vivokてHx ラット訮DNA 合成抑制活性を

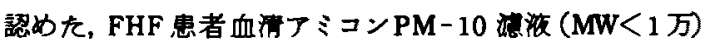
の5 5，9 例 (非A非B型 4 例。B 型 1 例，八ロセン 2 例。

Paracetamol 2例。全例死亡。) プールし, コントロール

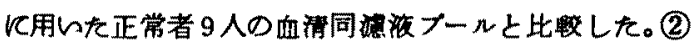
初代培盖肝細胞：中村らの方法に集じ、コラダナーゼ 灌流法儿て遊離肝細胞を得, $0.2 \times 10^{5} \mathrm{cell} / \mathrm{s} / \mathrm{ch}$ 密度 $\tau, 5 \% \mathrm{CO}_{2}$ 気相下 $37 \mathrm{CK} \tau, 10$ \% 胎児牛血淂加Willia -

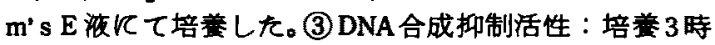
間て, (1)検体含的 $\mathrm{EGF}(10 \mathrm{ng} / \mathrm{m} \ell)$, Insul in $\left(10^{-7} \mathrm{M}\right.$ )

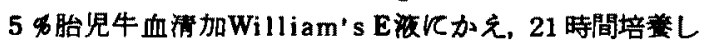
た。DNA合成活性は, $\left[{ }^{3} \mathrm{H}\right] \nsucc$ チシンのDNAへのとりてみて 求めた。またオートラシオオクフィーは培盖開始啳24時間 目より48時間目まて、肝細胞を $\left({ }^{3} \mathrm{H}\right)$ チミシンて僄識する ことにより行った。結果：(1)生食を投与した対照の DNA合成括性 $(\mathrm{dpm} / \mathrm{h} / \mu \mathrm{g}$ protein) の平均 $( \pm S D)$ 壮, EGF, Insul in 添加啳 1 日目に㤝 $56.7 \pm 16.6,2$ 日目に

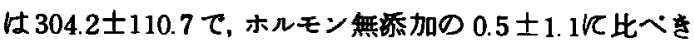
わめて高値を示した。(2)FHF患者血清 $M W<1$ 万の分 画は，対照の $2.7 \pm 4.7 \%$ K DNA 合成活性を抑制した ( $n=10: 3$ independent experiments)。一方, 等用 量の正常人血清源液て山，対照に比し有意の变化を示

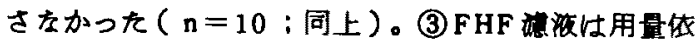
存的に DNA合成抑制活性を示した。 (4)FHF 源湤のDNA合 成抑制灶 reversible てあった。結論：制症肝炏患者血 清の分子量 1 万以下の分画炡，初代培誉肝細胞のDNA 合

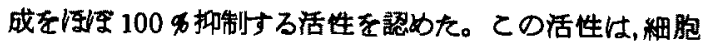
境死をおこさずDNA 合成を reversible 亿抑制した。in vivoおよび in vitroの双方て DNA 合成抑制活性を認 めをこのトキシンは，従来報告されていない新たな所 再生抑制物啠でる可能性が示唆され，制应肝筷の予 後不良の病的と密接に関係していると考えられる。 
31巻 suppl. (1990)

413 病態の解析

田中純次, 吉田正則, 田村 淳, 藤田研一, 笠松高行, 有井㴚樹，戸部隆吉

(京都大学医学部第一外科)

多䑏器不全(MOF)は, 敗血症, 肝硬変, 閉塞性黄㾝 等に合併して発生するか，その主要な成因としては， 肝機能不全加存在する。我々は，総括的な肝細胞機能 の示標として，膜流動性に注目し，実験的にラットに 閉塞性黄㾝, 肝硬変, 敗血店を作成し, 肝細胞膜流動 性が低下するととを報告してきた。今回，上記病態時 のヒト肝組織から細胞膜を分噰し, 膜流動性を梌討, 更に，MOF患者血装の膜流動性に及ほす影䇾につい て検討したので報告する。【万法】開腹時に，約 200 $\sim 300 \mathrm{mg}$ の肝組織を採取, sucrose gradient 下, 96,000 × g の遠心により，肝紐胞膜を分離、調整した。この 方法による膜成分純度は, $\mathrm{Na}^{+} \mathrm{K}^{+}$ATPase, 5'-nucleotidase, 6-Glutamyl transpeptidase, G-6-Pase, Succinic cytochrome $C$ reductase 等測定により評価した結 果，15〜20倍に純化され，ミトコンドリア，細胞質成 分等の混入は, 䣼素活性测定では認められなかった。 又, 調整された膜成分の電顕像でも，殆んどが細胞膜 成分であるととを確認した。分離膜の流動性は，1，6diphenyl-1, 3, 5-hexatriene を指標として, 偏光坟置 付分光蛍光光度計に $\tau$ fluorescence polarization(P)值

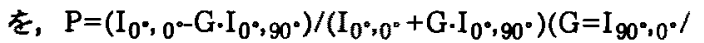

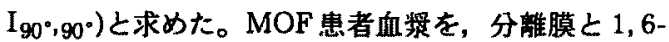
DPH のインキュベート時に添加，膜への影㹂をP 值

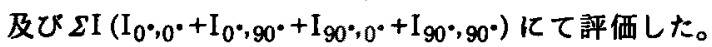
【結果】ヒト正常肝細胞膜 $P$ 值は, ラット肝細胞膜 $P$ 值 $0.180 \pm 0.004(n=24) 飞$ 比し, $0.193 \pm 0.005$ (mean \pm S.E.) と若干高值を示した。硬変肝では $0.211 \pm 0.005$ $(n=14)$ と正常肝に比し, 高値を示した $(P<0.02)$ 。同粎 $K$, 閉塞性黄㾝肝も $0.222 \pm 0.008(n=4, P<0.01)$ と 高值を示し, ラット肝硬変, 及び䦥塞性黄㾝モデルと 同粎の傾向を示した。一方, PTPE 後の再生肝ては, $P$ 值は $0.190 \pm 0.007, n=4$ と正常化回復する倾向を示 した。黄疸患者, MOF 患者血稰を分離正常膜 とインキュベートすると, 正常及び高ビリルビン血提

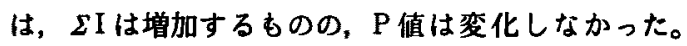
一方，MOF患者血浆は，逆比 $\Sigma \mathrm{I}$ 值を著明に下降さ せ，更にP值を上昇させた。尚，エントトキシン添加 は，P值上昇， $\Sigma \mathrm{I}$ 軽度增加を示した。【結論】以上， 閉塞性黄疾, 肝硬変等の多滕器不全準備状態の肝細胞 膜は，膜流動性加低下 ( $\mathrm{P}$ 值上昇) しており，MOF 患 者血频は，肝細胞膜流動性に直接影響を示した。
414 B型劇症所炎のウイルス変異株の検討

時田 元, 清水 睠, 星山面基 (忮皇県立伎皋病院消 化器科)，高橋善就太(同名誉院長)，小島等雄 (小 島内科クリニック)

【目的】通常，B 型急性肝炎例では初期にHBe抗原が 認められるが， B 型膚症盰炎では初期でる $\mathrm{HBe}$ 抗原か 認められない。B型耐应肝炎例の起因 HBVのHBe抗原 蛋白産生能を HBV-DNA レベルで解明するととを目的 とした。

【対象および方法】対象：B型研症肝炎 8 例（発症6力 月以内に輸血歴がある例 5 例を含み, 全例HBs 抗原お よび IgM型HBc 抗体陽性)および対照としてB型急生 肝炎 3 例。HBVのpre-C領域の塩基配列の决定方法: 患者血清よりDNAを抽出し，polymerase chain reaction(PCR)法により，HBVのpre-C 領域をふくも fragment 増幅した。堌幅した fragment をM13 phage vector亿組み込み，1本鎖の組み換えDNAを調整し， dideoxy chain termination 法で pre $-\mathrm{C}$ 領域の塭基配列 を决定した（測定は自治医大予防生態に訨頼した）。

【成績】 B 型㱆症旰炎8 列ではそれそれの血清から最 低 3 clones $\sim 23$ clones 加得られ，全体で 92 clones $の$ pre-C領域の㙁基配列が決定された。とれらの clones ではすべて第1896塩基がAになっていた。このためpre $-\mathrm{C}$ 領域の $\mathrm{N}$ 末端 28 番めのア AG・の stop codonとなり，"pre-C+C速层子“のpeptideは発現していないと考えられた。一方, 対照のB 型急性旰炎 3 例の血清より得られた clones では第 1896 塩基はGであり。したがって pre $-C$ 領域のN末端 28 番めのア トファンがcodeされており，・pre-C+C 遭层子・の peptideが発現されると考えられた。

【結論】 8 利のB 型滖应肝炎では HBe抗原の産生に必 要な signal-peptide t codeしている pre-core 領域で defectiveな変異株が全てであったが, 急性 B 型旰炎で は pre-core 領域の完全な wild-type が殆どであった。 との事はHBVの一過牲感染们わいて, 感染原のHBV が、そのstrainに依って異るった病態を示唆し、B型剖

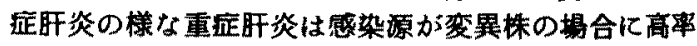
に出現すると考光られた。 
415 厔肝炎の予後因子の検討一 $-\operatorname{Cox} の$ 比例 ヘザード・モデルによろ多变量解析を用いて一 越野隄介，杉原閏一，白鳥義宗，安田盛，前田晃男， 松原由希子，友田 隆，村上啓雄，亲薕公郎， 森脇久隆，武藤泰䑤

（鮍鼻大学第一内科）

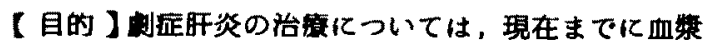

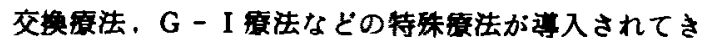
たが，全国集計をみると生存率の著明な改善はみられ ていはい。しかしながら，最近当教室では划叐肝焱急 生型の生存平は向上してきているととから，今回，Cox

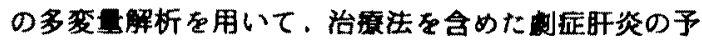
後に影啨を及はす因子について検討した。

【対象と方法】対象は，1973年より1989年に当科にお

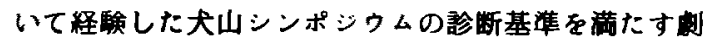
症所炎70例で，臨床病型は急性型39例(男21 例, 女 18

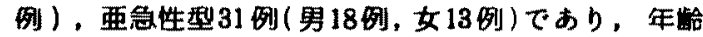

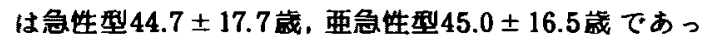

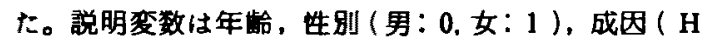

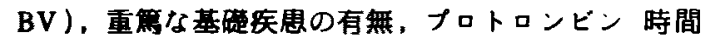

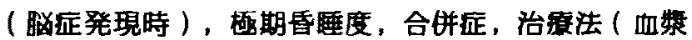

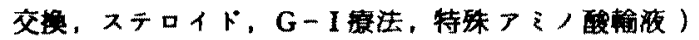
の11項目とし，発㱏から死亡（もしくは打ち切り）ま での日数を観測期間として，それそれの臨床病型に対 しCoxの比例ハザード・モデルを用いて解析した。

【結果】酒䀘炎の生存率は全体で $22.8 \%$ ，急性型 28.2 $\%$ ，覀急性型 $16.1 \%$ であった。各病型の説明変数の中 で䫓明力の高い変数の相関係数と限界確率示すと，

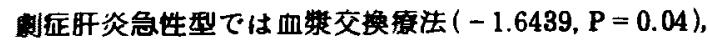
極期昏睡度 $(0.6238, \mathrm{P}=0.08)$ ，ブロロンビン時間

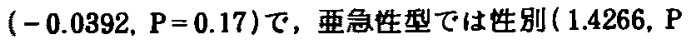

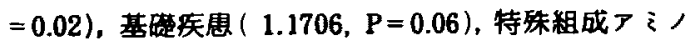

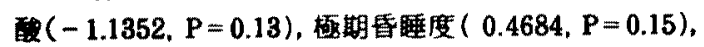

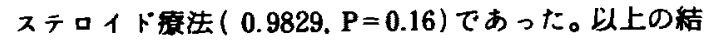
果より急生型では極期昏匿度の高いしのはど生存期間

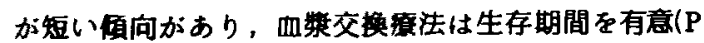
く 0.05$)$ 亿延長した。亜急性型では，女生，重第な

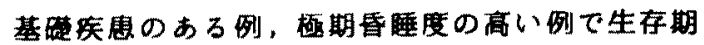

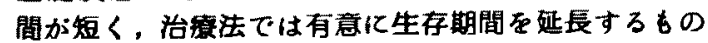
はなかったが，特殊租成アる，酸は生存期間を延長し ステロイド㾣法は生存期間を短編する傾向がみられた。

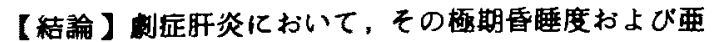

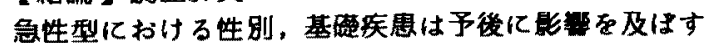

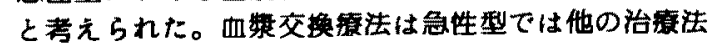
に比へ有奻と考元られたが，覀急性梨では予後を改善 しなかった。また，亜急性型の应例ではステロイド碾 法はその予後に要影帮を与えている可能性があり，治 癔に際しては留意する必要があると思かれる。
416

B型慢性肝炎の急性発症時の病態について 高口浩一, 山田用太郎, 遠藤久之. 西本 弘。 高橋美智子、松枝和宏、藤木茂第、水野元夫。 木野山真吾, 过 孝夫

（岡山大学第一内科）

【目的】 B 型慢性肝炎の急性発症時の病熊については 末だ不明の点が多い。今回われわれは $\mathrm{HBV}$ B キリア より発症したと思われる症例の肝組織内 $\mathrm{HBV}$ 関連抗 原. H L A -ClassI抗原ないしリンパ球サブセットの 局在を B型慢性肝炎患者の急性堌悪期と比較し，両時 期での肝細胞障害機序に差異がるか否かを検討した。 【万法】対象はB型旰炎キャリ丁より発症したと考え られた 3 例とHBe抗原淂性の恨性肝炎患者で急性增悪 期に肝生検を施行した 5例である。肝組織をPLP固定 し. 抗 pre-S1, pre-S2. HBsAg. HBcAg ないLHBeAg monoclonal 抗体 (特殊免废研究所). 抗HLA-ABC抗 体拟し抗 Leu2a，Leu 3a,Leu7抗体(Becton Dickinson)を一次抗体とし. HRPO標識家鬼抗マウス免废グ ロブリン(Fab')を二次抗体とした酥素抗体間接法にて 検討した。血中 $\mathrm{HBe}$ 抗原・抗体は RIA法で, DNA-P 值はKaplanの変法にて测定した。

【成績】急性発症例では䀒組織内HBs.pre-S2 抗原 は全例膜およひ絧胞啠型を示したのに対し、pre-S1抗 原は 1 例で膜および細胞質型. 2 例で細胞罂型であ， た。 $\mathrm{HBc}$ 抗原は 3 例とも核およひ細胞質型を示し, 膜 型を示す肝細胞も散在性に裸察された。HBe 抗原は全 例で $\mathrm{HBc}$ 抗原とほほ同様汇核および細胞質型であっ た。一方, 慢性肝炎の急性增悪例では pre-S1 抗原は 5 例中 3 例て除性。2 例て細胞質型を示した。 pre-S2. $\mathrm{HBs}$ 抗原は 3 列で膜および細胞質型，2 例で細胞質

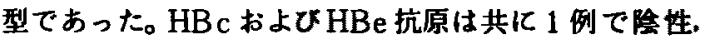
他の 4 例はすへて細胞質型を示し，年的にす堿少が認 められた。

またHLA-Class I 抗原はともにび侵性ないしは局所 性に增強し、リンパ球サブセットでは cytotoxicTリン パ球の增加が雨者ともに認められた。

【結語】1. 急性発症時に比して急性增悪期の方か pre-S 1 およびHBc抗原是ともに少ない颃向があった。 2. 急性発症時にはHBc.HBe抗原とむに核およひ細胞質 型が多く，一部に膜型を示す $\mathrm{HBc}$ 抗原か認められた。 一方, 急性增要期《は $\mathrm{HBc}, \mathrm{HBe}$ 抗原とむに細胞質型の例 が多かった。また膜型を示す pre-S1抗原は両時期と もに認められなかった。以上よりキャリアからの急性 発症の病態としては coreペプタイドないしは pre-S1 抗原を標的とする $\mathrm{T}$ cell cytotoxicityの関与が推测 された。 
417 九州地区における原発性䀒癌切除例と予後 规定因子の鈢部一九州旰瞹外科研究会一

瀨川徹，井沢邦英，士屋凉一：長崎大学第 2 外科

近年, 原発性䀒細胞癌（肝癌）の切除例は增加し鹿期 生存例も散見されるようになってきた。しかし旰癌は

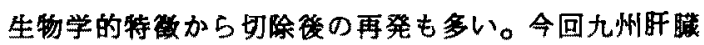
外科研究会では九州管内における肝瘦を集計し地域性

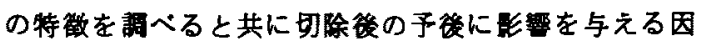
子につき検討した。対象および方法 : 九州管内29施設 における 1982年1月から 1988 年9月までの旰癌切除例 664 例を対象とした。男性548例，女性116 例であり年

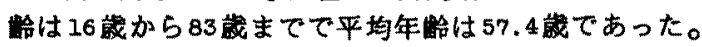
険討項目は䀒癌取扱規約に準じ諸因子別の累積生存率 をKaplanーM日ier法により算出し予後規定因子を検討 した。また可除後の再発形式, 各因子別の無再発率に ついても検討した。結果：症例の背景因子としては， $\mathrm{HBs}-\mathrm{Ag}(+) 165$ 例， $\mathrm{HBe}-\mathrm{Ag}(+) 40$ 例であり，食道静 眽瘤の合併は22.8\%であった。臨床病期分類では 1 期 $72.5 \%$ ，1期 $26.8 \%$ ，期0.7\%であった。術前のAFP 值は $20 \mathrm{ng} / \mathrm{m} \ell$ 以下は34.2\%，1001 ng/me以上は $19.7 \%$ であった。癌腫は単発例が79.5\%と多く, Fc (十) 83.0\% . Fc-lnf $(H) 37.5 \%, \mathrm{Sf}(H) 41.7 \%, \mathrm{Vp}(82.6 \%, \mathrm{M}()$ 73.9\%, 腫㻛の大きさで妒 $2 \mathrm{~cm}$ 以下は24.1\%であり, $\mathrm{cm}$ 以上は29.6\%であった。細胞異型度では Edmondson Iが65.9\%と最も多く，Stage分類ではStage I が45.6 タであった。䀒切除術式ではHrO28.7\%, HrS 35.3\%, $\mathrm{Hr1} 17.9 \%, \mathrm{Hr} 2$ 16.2\%, Hr3 1.9\%であった。TW(十) は38.4发であり，手術の根治度では䋑対治痹切除は13。 $6 \%$ ，相対治场切除は $48.0 \%$ ，相対非治癁切除は 33.0\%

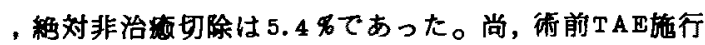
例は40.2\%であった。また再発例(237例)における肝 内再発形式は断端再発 $12.4 \%$, 同葉再発 $27.2 \%$, 対側

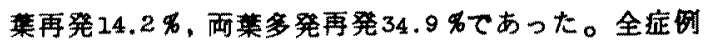
の累糟生存率は工生率70\%，3生率46\%，5生率29\%で あり，無再発生存率は1生率59\%，3生率30.5\%，5生 事18\%であった。Stag・分類による1，3，5年果程生存 事はStage Iで $88 \% ， 76 \% ， 61 \% ，$ Stage IIで74\%，48\% ,22\%, Stage IIでは54\%，29\%，23\%と各群に有意差を

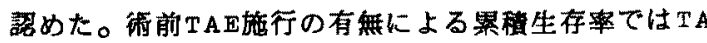
E施行例が非施行例に比し有意に良好であり，特にSta geII，林においてTAEの有用性が諗められた。その他累

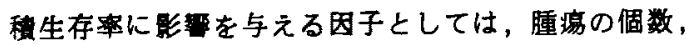

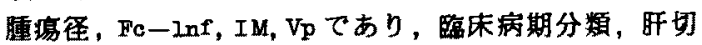
除術式，街前AFP值、Fc，HBE一Ag の有無などにより 生存率に差を認めなかった。しかしHB日一Ag(十)例は (一)例に比し予後不良であった。結語：九州管内にお ける䀒癌切除例を検討し，予後に影翌を与える因子を 決定した。特に術前TAEの有用性が認められた点が注 目された。
418 䍀小肝愿の切馀成真

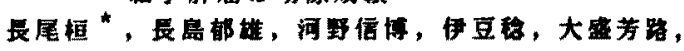

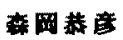

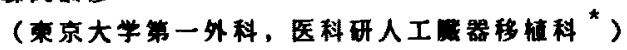

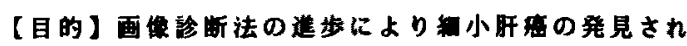

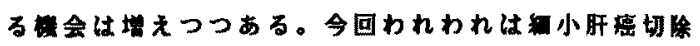

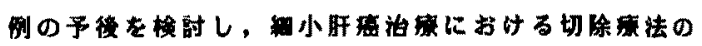
意黄を考察した。

【方法】1979-1988年の10年问の当施殿における䋖小

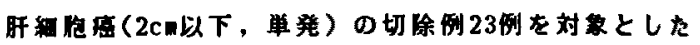
・人院病歴，外来病歴を琱枯することにより，その病

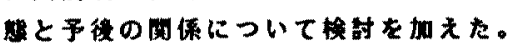

【成耧】23例の男女比は19:4, 平妁年峆は56.7感(31-

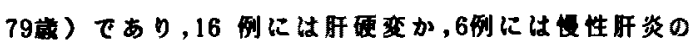
併存かみられた。切涂梅式は1列が旰菜切馀，3例か区 域切除，他の19噺《旰分切除であった。

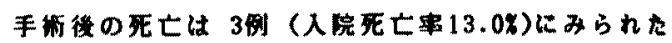
が，他の20例は彗事退院した。この20例の街後1，3 ，5年生存罗はそれぞれ90.0,79.1,61.07 たすり，同

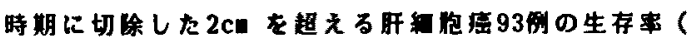
1 年, 82.0\%; 3 年, 51.1\%；5年, 36.7\%)上り良好 であったが，他器器の早期空切馀成辕に比して清足す

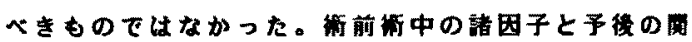

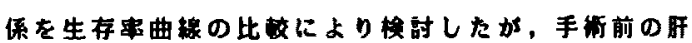

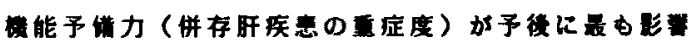
した。また退院掼すてに死亡した6例の検封では，全

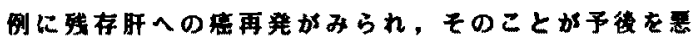
くした。

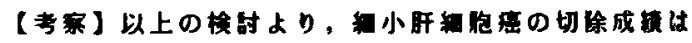
他裙器の早期殓に比して不良であることが判明した。

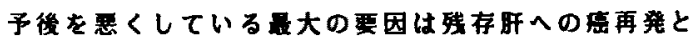

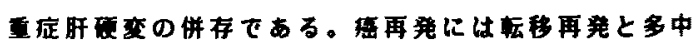

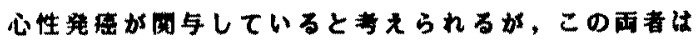
䀒硬交の存在に密接に问速する。すなわち硬变肝ては 旰予借能の不足により切除汻客量が制限されるため枟

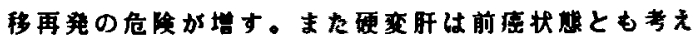

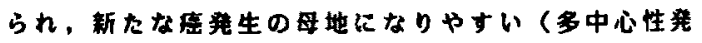

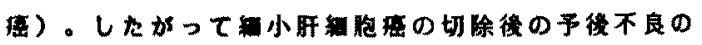

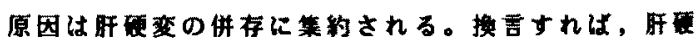

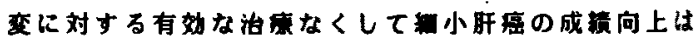

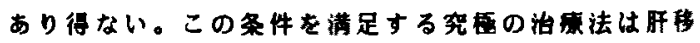
继のみでろう。

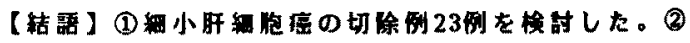

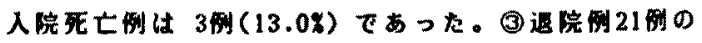
1，3，5年生存事沬90.0,79.1,61.0\%であった。(4)

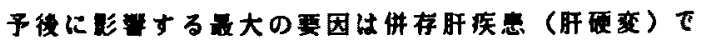
あった。(5)成浩向上のためには肝移殸が期待される。 


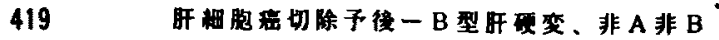

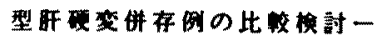

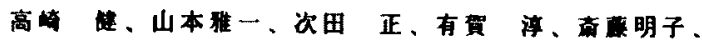

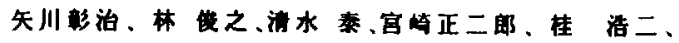

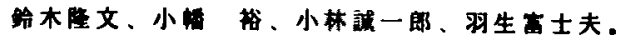
(東京女子医科大学、消化器宔センター)

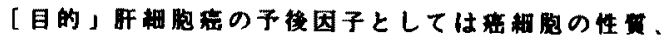

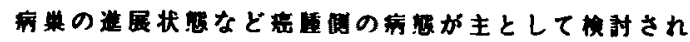

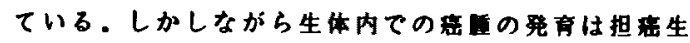

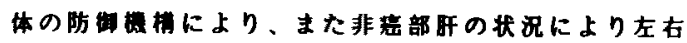
され挠にも影してくるいのと考えられる。ここで

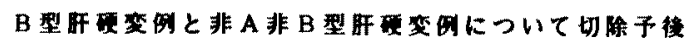
の模討を行った。

[模討对象およひ方法]1985年度までに切除侍が行わ

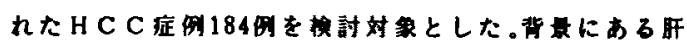

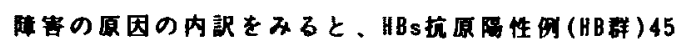

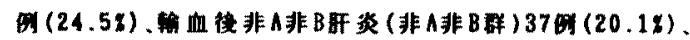
フルコール、その他102国(55.48)である。こんの症间 についてその切除予嵝について部した。

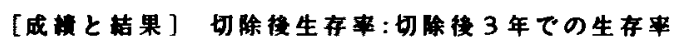
は、HB群全体ではそれぞれ56るであるが非A非B群では

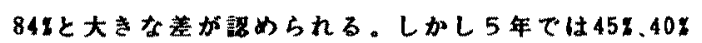

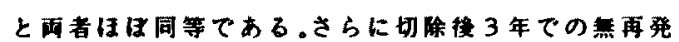
生存事について榾討すると生存本とは迹で湖全体で は31.8\%.であり、䑳血群では16\%である。すなわち昭 は非へ非B群より俌昸早期死亡间は多いが 3 年、5年で

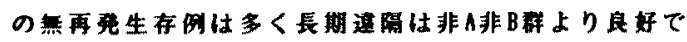

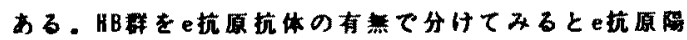

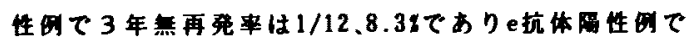
は12/20，60.08である。抗体降件での3 年以内の再

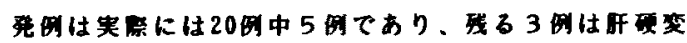
に起因した舡不全死である。明らかにe抗体阳性に 再発が少ない。そこで次に胴群についてe抗原。轨体

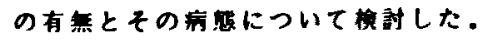

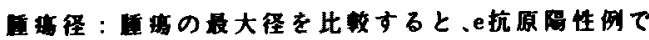

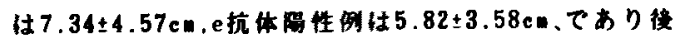

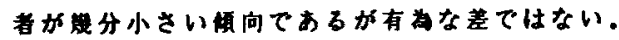

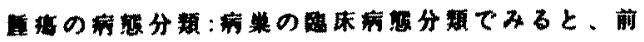

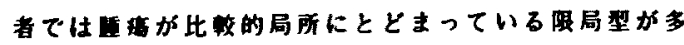
く、半數以上を占的ているがe抗原四性湖では周囲に 䧿展した型の比率が多い㑯向である。しかしe抗体田性

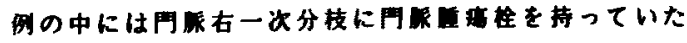
症例が 2 列あるがとしに5年以上焦再発生存中である。 [诘語]

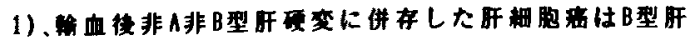

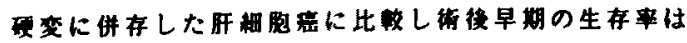
一見良好であるが、逗隔予後は不主である。

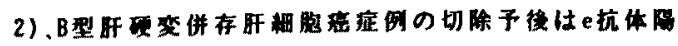

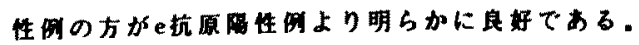

420 肝細胞舶切除後再発例の病腎とその対策 横井一，下村 誠，山際健太䬦，石田亘去， 東口高志, 野口 孝, 川原田嘉文, 水本龍二 （三重大学第一外科）

近年肝細胞癌の切除成績は向上してきたか, 術後の 再発は㑈然高率でおる。そとで今回, 再発肝癌の病態中 その対策を明らかにする目的で以下の㮆討を行った。 【対象，方法】最近13年間に教室で経殹した肝細胞癌 切除例 115 例のうち術後再発例53例を中心に腫瘍進展 度や,核 DNA ploidy pattern, 肝機能などの面から再発様 式中再発時期等との関連並びに再発例や再発予防の対 策について検討した。【成績】1)再発時期：53例中獄 後 2 年以内に再発を来したものは 42 例(79.2\%)で, 原発 单が単発例では術後平均 1.9 年と多発例の 0.9 年に比し 長く，また vp(ー)では 2.4 年, $v p(+) 1.1$ 年, $\mathrm{Vp}(+) 0.4$ 年 と門脈侵慗か高度のものほど早期に再発を来した。ま た非治虑切除例でも ploidy pattern が diploidのものて

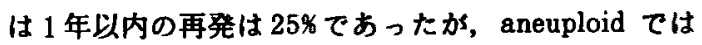
$85.7 \% か ゙ 1$ 年以内に再発した。一方, 肝線稚化率か20\%以 下のものでは 1.2 年と線維化率 $20 \%$ 以上のものの 2.2 年 に比し早期に再発した。2)再発様式: 再発確認時の再 発腈器は残肝のみか $84.9 \%$ と最も多く, ploidy patternで は diploid か69\%であったのに対し, 残肝十肝外搭器, 肝 外臈器のみの再発がそれぞれ 9.4\%，5.7\%に認められ， れらは aneuploidか $80 \%$ を占めた。3) 再発時の肝機能 と再発様式: 再発時,教室の総合的 risk か 1 2 と良好 であった18例では全例再発䉓は多発であったが, 総合 的 risk 4 を示した 5 例は全例腄㻿经は $3 \mathrm{~cm}$ 以下で,かつ 4 例か単発再発でおり, 形態的に再切除可能なものほ ど高度肝障害例が多かった。4)再発例の治害成綪: 再 切除を行った 6 例中 1 例には再っ切除, 他の 1 例には 肺輀移巣を同時に切除し，さらに最近では再発時の総 合的 risk 4 と高度肝障嗐を量した 1 例には経横隔膜的 再切除を行っており, 再発後累皘 3 年生存率は再切除 例では 25\% と Lipiodol-TAE施行例 (14例)の9\%に比し 良好て，その他の治療法ては再発後 2 年以上の生存例 はなかった。5) 術後再発予防の対策: 術後早期の耐注 化学楼法施行例の累皘 2 年無再発率は $64 \%$ と非施行例 の 48\%に比し良好て, また最近では腫場進展度やDNA ploidy patternを考巵して 5 例に術後予防的に動注リザー パ留圈を行い，積極的な動注撩法を行っており，術啳 3〜12ケ月の現在良好な経過を得ている。【結語】肝癌切 除後の再発は術後 2 年以内に生ずるものが王倒的に多 く，とれらの対策としては腫韵進展度や DNA ploidy pattern等を考后し，術後早期より予防的に棈極的な動 注化学薏法を行うことが重要である。牫肝再発例では 再切除可能例では肝機能面からは risk不良例が多いか， 槙重な術前術後管理に加え，手術手技の工夫を行うこ ととにより予後の向上が得られるむのと考えられる。 
421 腫瘄徍 $3 \mathrm{~cm}$ 以上の肝紐胞癌に対するエタノー 几注入療法の効果判定法について 一造影剂湿注によ 万経皮的腫陽造影の検討 -

猫椅俊文 ${ }^{1}$, 森本 晋 ${ }^{1)}$, 込山賢次 ${ }^{2}$, 里井重化 ${ }^{1)}$,

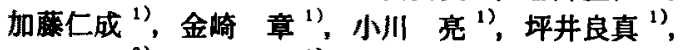
宇井忠公 ${ }^{2)}$, 田中照二 ${ }^{1)}$

（東京慈恵会医科大学第三病院内科学第 1 講座 ${ }^{1}$, 東 京共济病院内科 ${ }^{2)}$ )

【目的】腫癌徍の大きな肝細胞癌(HCC)に対するエタ ノール注入粪法(PEIT)の効果を高めろためには, 適 切な効果判定法の確立がのぞまれる。PEIT直後に効果 判定をすることは，以降のエタノールの注入部位，注 入量，注入回数を検討する上で良い指標となるである う。そとでわれわれは，效果判定法の1つとして腫呁 圣 $3 \mathrm{~cm}$ 以上のHCCに対し造影郕混合エタノール注入存 法(CM-PEIT) を施行し，造影剂による原痻造影像と エタノールに上る腫癌壊死効果を対比梌郡したので啹 告する。【方法】当院および当院関連病院で画侓猃断

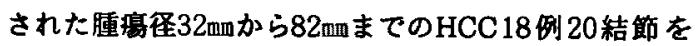
対象とした。併用祢法としてTAEを施行したもの13例 13 結節, PEIT 単独加 5 例 7 結節でった。CM-PEIT はェコーカイト下に18G PTC針にて呀刺し, 70\%の濃 度に調製した造影剂混合エタノールを注入後 2 万向よ クレントゲン掫影、翌日CTを施行し腫湶造影像を検 討した。再度施行する際は非造影部に穿刺注入し, 最 終的に腫瘍全体の造影像が得られるまて施行した。18 例中 9 例飞肝切除, 4 例 ( 6 結節)に剖梌を行い腫㙞壊

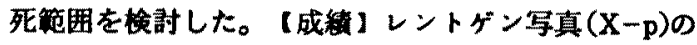
尾䌿造影像では, 20結節中15結節が well enhanced, 3 結節が moderately enhanced, 2 結節加 poorly enhanced であり, well enhanced の結節はPEIT後期 間のうちに肝切除した 1 例を除き14結節すへてに腫疱

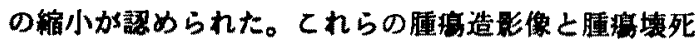
率を肝切除および剖検例15結節で検討すると，well enhancedの12結節は各割面の病理学的検討て85\%以上 の壊死率加得られ，う58結節は $100 \%$ の完全塤死か

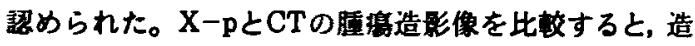
影箅囲は骤ね一致していたが のTの方がより鲜明な画 像であり，造影部と非造影部とのコントラストが明暸 であった。CTの造影像と病理組織像を検討した 6 結 箇では，全体が造影された 4 結節のうち 1 結節に91\%， 3結節に 100 多の境死率が認められた。他の 2 結節に おいても腫瘍造影された部位に一政して罗死か認めら

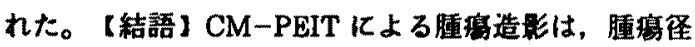
$3 \mathrm{~cm}$ 以上のHCCに対するエタノールの注入部位，注入 量，注入回数を検討する上で良い指標之なり，さらに 腫境壊死効果を判定する上で非常に有用な方法である ことか示啐された。
422

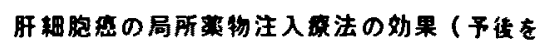
主体とする梌討)

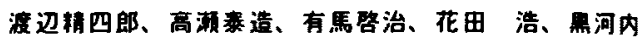

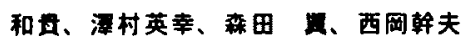

(香川医科大学第三内料)

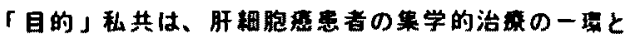

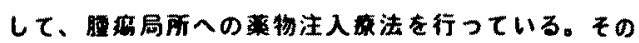

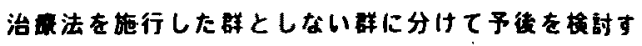

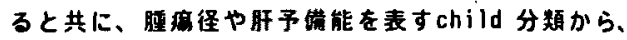
どのような患者に局所菜物注入法が初果的かを损討 した。

「对象及ひ方法」香川医科大学第三内科に入院した䏸

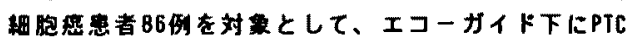

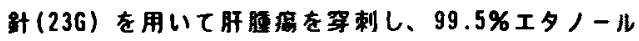

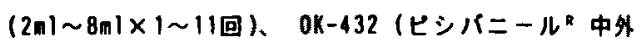
膂董 10KE 35KEX1〜回)、インターロイキン2(TGP

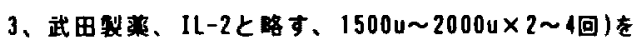
それそれ局所注入した。

「成䋖」エタノール注入群；2261に注入し、そのうら 手街的に摘出された 2 仙には、注入部に広く境死が现

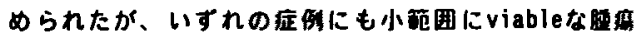

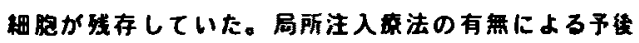

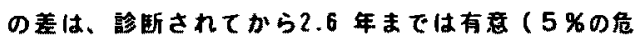

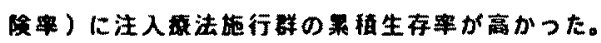

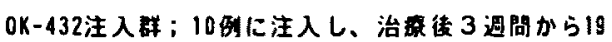

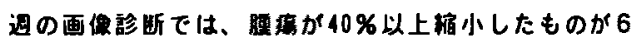
田であった。局所注入法の有無による予後の差は、

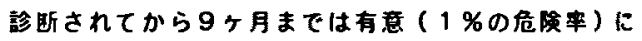
注入法施行詳の罢程生存率が高かった。

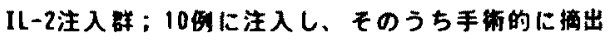
された 4 例の接行では、本治张法の有無による予徒の 差は症挒数が少なく、十分格㣙されていない。

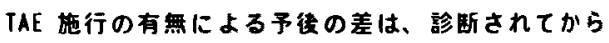

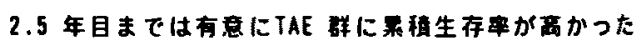

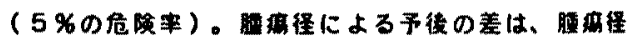
が $3 \mathrm{~cm}$ 以下と $3 \mathrm{cm \sim} 5 \mathrm{~cm}$ 症脷では大差がなく、 $5 \mathrm{~cm}$.

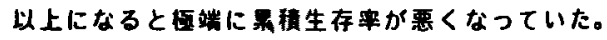
Child 分類による予後の差は、A以外は生存粱が蓄し く低く、はとんど 1 年以内に死亡していた。肝相胞程

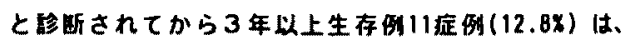

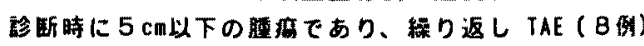

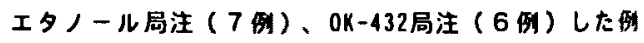
であった。

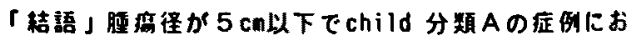

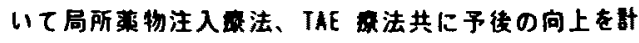
るために有初な法と考えられた。 
423 局所動注㫫法の新しい薬制としての固形型 エトポシドの抽出とその基磁的検討

馬場芳郎, 坂下博橵，古川泰典，今村純博，山口幸一, 有馬㖓勝（鹿児島大学医学部第二内科）

中村和男, 本屋敏郎, 石橋丸意（同附属病院楽剂部）

【目的】エトポシド $(\mathrm{Et})$ の腫蜳奻果は高く評価されて いるがエトポシド製削動注時の血王低下，ショックか 報告されておりほとんど局所動注㛥法に応用されてい ない。今回我々はラステット・注（日本化薬）より Et を固形型Etとして抽出しエトポシド・リピオドールサ スペンジョン（EOS）を作製しその臨床応用を目的 として基磷的検討を行った。

【方法】1）EOSの作製：ラステット注に注射用 蒸留水を加元摚拌後静置し得られた白色結晶性沋殿物 を連心分部し洗浄後蒸発乾固させ固形型Etを得，モ， ステアリン酸オイルサスペンションを加え愁淂させ EOS (Et 20mg/ml含有) を作製した。2）放出性の 换討：透析用セルロースにEOSを入れ生理食塩水へ のEt放出率を経時的に测定した。次にラットを開腹し 門眽よりEOS $0.2 \mathrm{ml} / \mathrm{kg}$ (Et $4 \mathrm{mg} / \mathrm{kg}$ ) を投与し経

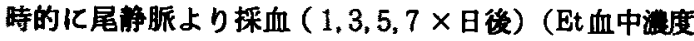

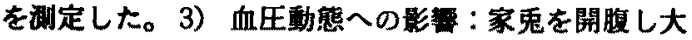
腿動脈王モニタ一下に固有肝動脈より EOS $0.2 \mathrm{ml} / \mathrm{kg}$

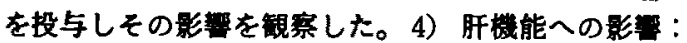
ラットの門脈より EOS (Et20mg/ml, 40mg/ml), リ

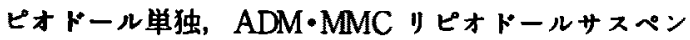
ション (ADMOS, ADM $4 \mathrm{mg} / \mathrm{m} l, \mathrm{MMC} 2 \mathrm{mg} / \mathrm{ml}$ 含 有) を各々 $0.2 \mathrm{ml} / \mathrm{kg}$ 投与後経時的 $(1,3,5,7$ 日後) に採血し肝機能に及にす影䇾を比较検討した。

【成績】放出性の実験では高い徐放性加認められ，血 中暇度测定においては投与 1 日後に平均 $0.14 \mu \mathrm{g} / \mathrm{m \ell}$ と微量検出されたのみでその後は㑚定感度以下であ， た。EOS動注後30分間にわたり動脈仕の资勳は認め なかった。動注後肝機能検查においては各群とむ投与 1 日後をピークとする肝機能異常が認められたが一過 性で7 日以内に回復した。総ビリルビンの上昇は認め られすＧＰ佸性について見るとEOS群はリピオド 一ル単独群に比し有意な上昇を示したか，高瀑度EOS $40 \mathrm{mg} / \mathrm{ml}$ 群においてもピーク時 G P T 活性（平均1299 $\mathrm{KU}$ ) ADMOS群 (平均 $2554 \mathrm{KU}$ ) 飞比し有意任低値 であった。（危险率 0.05 以下）

【結論】我々の作㡀したEOSは高い徐放性を有し， 血圧に影䇦を与えず，動注後一過性に肝障害は認める ものの，その障害性は従来広く使用されているADM OSより低くEOSの動注化学耚法への学入は充分可 能であるものと考えられた。
424 レーザー球状凝固法に上る所㿋治療の效用

橋本大定，椐原周二，長谷川侼二，執行友成，

佐野 淳, 高橋寿久，斉藤慶一，出月康夫"

（東京整察病院消化器センター外科）

(東京大学第二外科 ${ }^{*}$ )

【目的】本邦に於る原発性訮癌の治療の分野では，合 併する肝障害のゆえに，上り侵襲が少なく，かつ，局 所根治性が高い治瘄法の模霜がつつけられている。我 々は，肝切除することなく，肝癌部だけを選択的に㓋 固させることを目的として、レーザー球状凝固療法を 開発し，その治療応用を行ってきた。

【方法】 $600 \mu$ 佳のNd-YAGレーザーの曾光フェイ バ一の特先端加工 (二段中錐先端球面加工)により， 先端部で球状にピームが拡散する特殊石英フォイバー を作成した。同フォイバーを肝に刺入して、レーザー 連続照射を行 5 ，照射エネルギーに比例して球状の

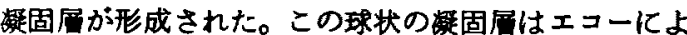
り球状の高エコー域として明膫に観繁された。レーザ 一凝固首の中心部では，組織の蒸散に伴ってガスが発 生するので，このガスを肝外俆去する三方開管萃置 を考案した。レーザー穿刺治㞠は原則として開腹下て 行った。まず肝癌をエコー観察下に $30 \mathrm{~cm}, 15 \mathrm{gauge} の$ テフロン針で穿刺する。ついで内简を抜去し，球状照 射型レーザーフォイバーをテフロンカニニーレのなか に㨀入し，その先端部をテフロンカニューレの先端よ ク 2-3 ma先の部分に位置させる。三力開管の側管に持

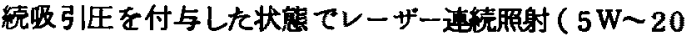
W) )行了。照射総エネルギー量は，肝稗の推定最大 体栍（エコーで描出さ机る最大直往を有する球として 計算） $m \ell \times 600$ joules とした。また照射治療の確実性 を術中ェコーにて確認した。

【成績】原発性肝癌 8例，枟移性肝癌 6 例にレーザ 一球状凝固治療を行った。照射治療媵腫瘍マーカーは いつれれす著明に低下した。膠射治療媵、一過性の発熱 と肝胆道采酸素の上界の他仙重第な合併症はなかった。 肝瘦の多発している症例では，肝動脈に動注用カテー テルを㨂入し、術後，動注化学潦法を併せ行った。本治 療法の特徽として以下の点を挙げることができる。

1. レーザー凝固層が里く形成され，そのなかで血

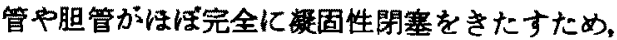
術中、術後を通じて出血や胆汁の漏出がみられな い。

2. 直膲 $5 \mathrm{~cm}$ までの肝榣は、1 1 回の穿刺で短時間の 間にレーザー球状瀑固が容易に行える。 （20W连繶照射では 33 分）

3. 術後肝障害が軽豚である。

【結論】原発性肝癌中枟移性肝癌の治療に於て、レ一 ザー球状凝固法の有用性は高いと考える。 
(目的) 我々は第23回肝学会においてTunor Necrosis Factor(TNF) とInterferon- $r(I F N-r)$ とを併

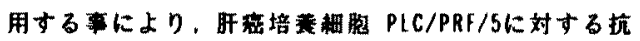

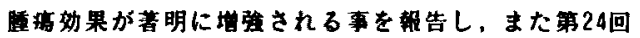

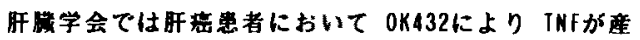

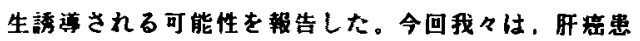

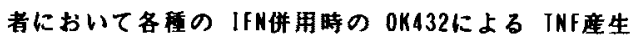

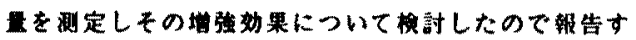
る。

(方法) 肝密息者(HCC) 8 名、建常人 3 名の末梢血单

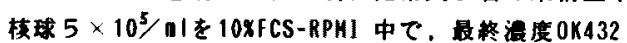

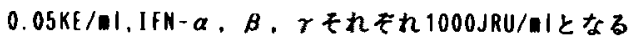
上う单独で，また，周湜庭の0K432とIFN- $\alpha 、 \beta, \gamma$ それをれとを併用で、12h，24h湿合培意し，培黄上清 中のHunan Iunor Mecrosis Factor Aldha(TNF)をELISA法(Endogen, Inc. 新震キット)で成定した。

\begin{tabular}{|c|c|c|}
\hline & $\mathrm{HCC}$ & Heal thy \\
\hline cont & $475.6 \pm 231.8$ & $236.2 \pm 76.4$ \\
\hline IFN- $\alpha$ & $1360.8 \pm 488.7 * \mid$ & $302.5 \pm 106.1$ \\
\hline IFN- $\beta$ & $1362.2 \pm 495.4]^{* * * *}$ & $288.8 \pm 79.9 \stackrel{* * \mid}{* *}$ \\
\hline IFN-r & $2301.3 \pm 924.6$ & $677.6 \pm 119.7]$ \\
\hline OK432 & $3146.6+892.4=$ & $2788.0 \pm 391.4 \square$ \\
\hline $0 K+\alpha$ & $3420.1 \pm 760.1$ & $2717.4 \pm 542.1$ \\
\hline $0 \mathrm{~K}+\beta$ & $3344.2 \pm 706.5$ & $2141.4 \pm 736.8$ \\
\hline $\mathrm{OK}+r$ & $3895.2 \pm 690.9 \mathrm{~J}$ & $2567.8 \pm 933.1$ \\
\hline
\end{tabular}

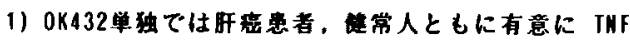

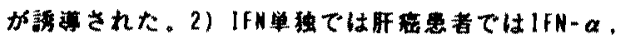

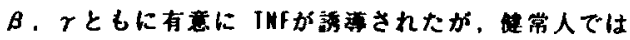

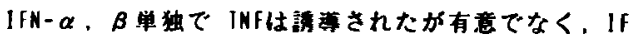
Nーrでのみ有意であった。3併用では，12h後では传 常人においては 0K432算に比しIFN- $\alpha, \beta ， \gamma$ とも

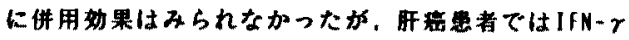

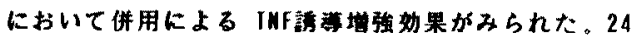

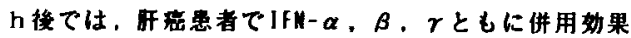
がみられ，特にIFNーてにおいてその协果が著明であっ た。

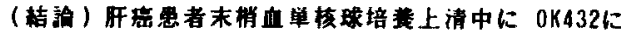

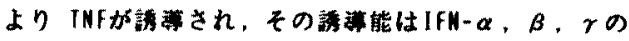
併用により剒強され，とりわけIFNーrで著明であった 。以上より OK432と各㮔IFHの併用によるINFを介し

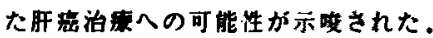

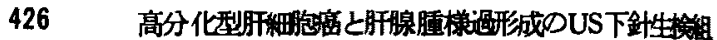
織診断におりる緗胞密度比及ひ核DNA量比の有用性につて 伊藤嘉信，宮内聡一郎，赤松興一，太田康幸

（爱媛大学医学部第三内科）

(目的】US下針生検により確定診断される肝細胞癌 (HCC)加增加している。しかし細小肝癌 (SLC) は 高分化型のものが多く，従来の診断基準ではH C CD 診断が困難なととが多い。今回我々はU S 下針生模て 得られた組織を用い，高分化型のH C C の診断に有用 な組織学的特徵を肝腺腫様通形成 (Ad H) との比较に より検討した。

【対象及び方法】対象は過去 2 年間に当科で経輇した 最大径 $2 \mathrm{~cm}$ 以下で単発の肝内結節性病変のうち,エコー

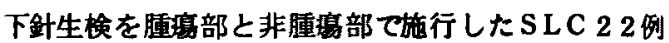
(Edmondson I 型8 例, II 型 10 例, III型 4 例) 及ひ AdH 8 例の計 30 例である。組織学的梌討では, 生梌 組織のH E 染色標本で、腫塂部之非腫㹸部のそれそれ 単位面棈当りの細胞数を求め。その比を蕾宜部/非湟 䅣部の細胞密度比として算出した。また鍍銀染色標本 て，肝細胞索の楼造の変化についても検討した。更に パラフィン包埋した厚さ $10 \mu \mathrm{m}$ の切片を脱バラ後，4， 6-diamidino-2-phenyl indole (DAP I)により染色 した後，顕微分光測光 system (UMSP, Carl Zeiss

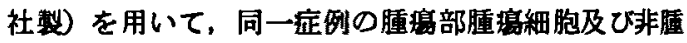
揘部肝細胞それぞれ 180 個の核DNA 量を测定し, 各 症例の腫湯部核 DNA 量／非腫瑒部核 DNA 量比を算出 した。

\section{【成績】}

1. 細胞密度比 : 腫部部/非腫部部の細胞密度比は

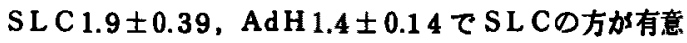
に高かった $(\mathrm{P}<0.01)$ 。

2. 肝細胞索 : $\mathrm{AdH}$ の肝細胞索付すへて1 2 首を示 し. SLCでは 3 届以上の槽造を示すものが多かったか， Edmondson I 型では 50\%が Ad H と同棣の $1 \sim 2$ 首の 構造を示した。

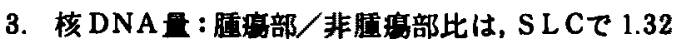
$\pm 0.20, A d H て ゙ 0.99 \pm 0.09$ となり S L C 加有意化高加 つた $(P<0.01)$ 。

4. Edmondson I 型と AdHの鏃別: I 型の SLC, 8 例はす へて細胞密度比 1.5 以上核DNA比 1.04 以上であった。 【結論】S LCとAdHの組織学的特徽をUS 下針生検組絇 の腫度部之非腫疸部の細胞密度比, 肝細胞索の榑造，核 DNA 量比について検討したとてろ，1.SLCではAdH

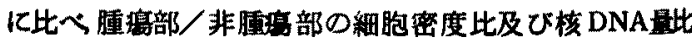
か有意に高く，肝細胞索は多層化を示すことが多かったが、 てれらの 1 項目のみの特改から AdHと Edmondson I 型の 高分化型のS LCとの鑑別は困赫であった。2.勫胞密度 比が 1.5 以上でかつ核DNA 量比が 1.04 以上の腫的は， すへて高分化型の肝細胞盘と，㟝断可能であった。 
427

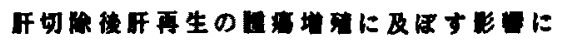

วいर

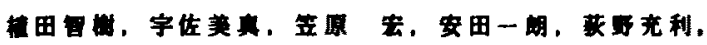

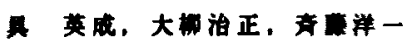

(抑戸大学察一外科)

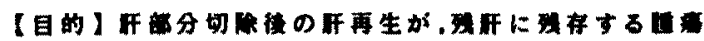

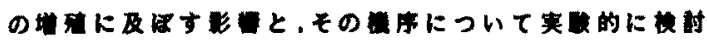
し*.

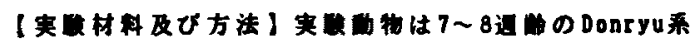

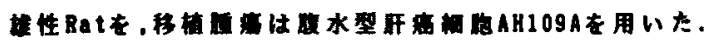

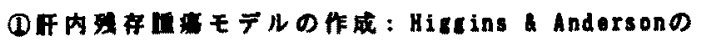

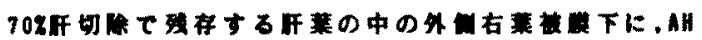

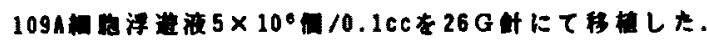

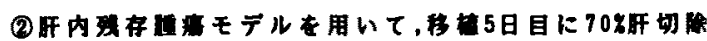

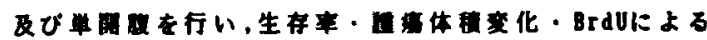

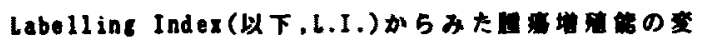

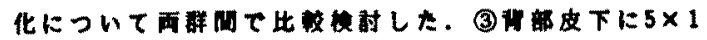

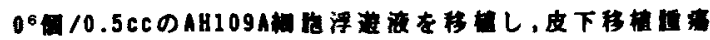

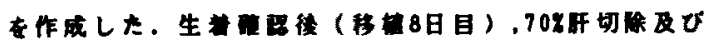

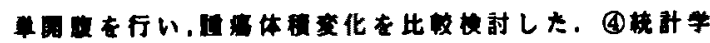

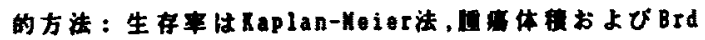

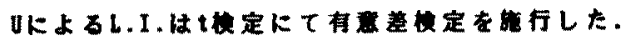

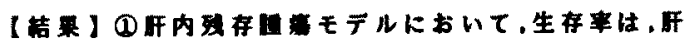

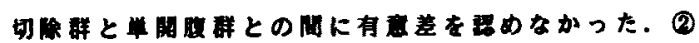

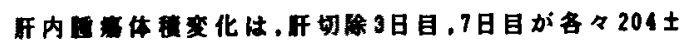

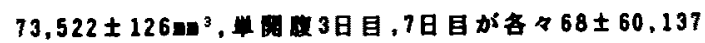

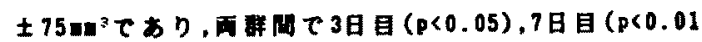

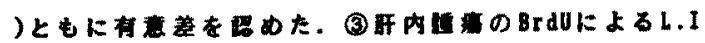

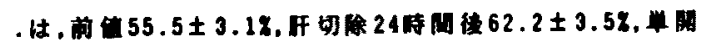

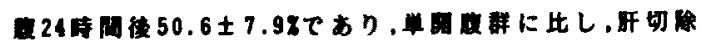

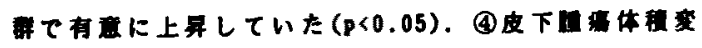

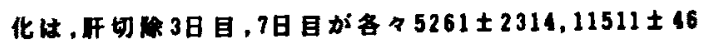

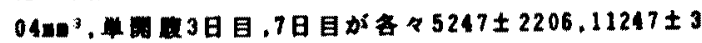

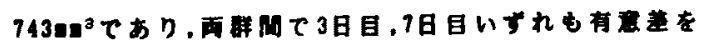
既めるった。

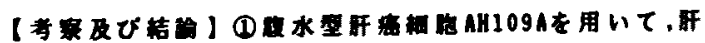

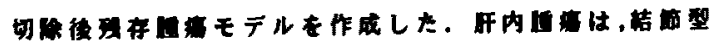

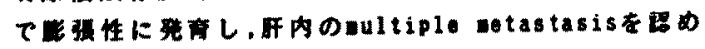

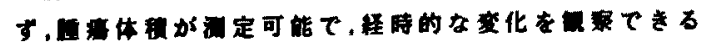

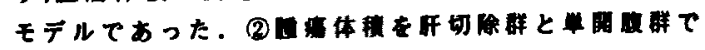

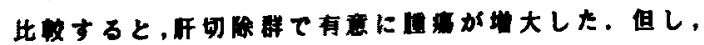

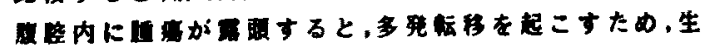

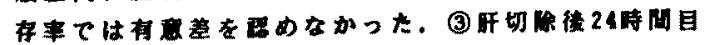

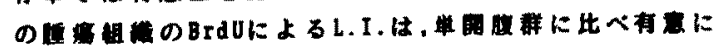

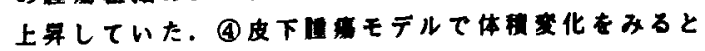

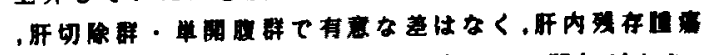

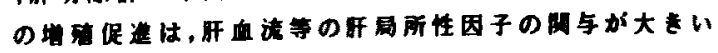
むのと示唓された。

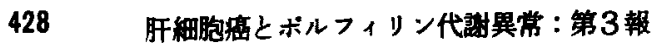
肝婑脈塞栓術前後の尿中ボルフィリン体重分画の変動 とその臨床的意義について

城江裕、山田貞子、星野 潮、河野通盛、長谷川真 弓、陶山和子、加藤誠一、周防武昭、川崎宽中（鳥取 大学第二内科）阿部硬司（塩野義製苯医科研） 久 谷頼信 (シオノギシイオメディカルラボラトリー)

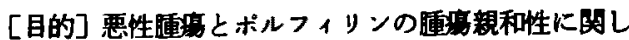

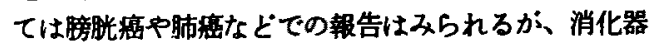
癌とりわけ肝細胞癌 $(\mathrm{HCC})$ での報告ははとんどみら

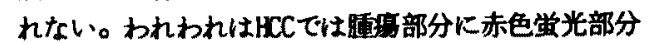
のみられること、肝硬変に比べて尿中コブロー、ウロ ボルフィリンが有意に增加し、コプロI 型が四型に比 して增加することを本学会て報告してきた。今回、肝 動脈塞栓術（TAE）前後で尿中の各锺ボルフィリン異

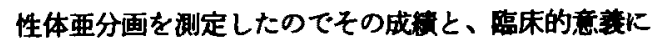
つ、て報告する。

[万法] 対象は非切除HCC1O例であり12回にわたりTAE を施行した。TAE前、1日、3日、5日、7日目に尿を採 取し尿中ポルフィリン体6分画即ちウロポルフィリン

(UP) 、ヘブター（TP)、へキサー（GP）、ベンタ（ 5P) ポルフィリン、コプローI（CP-I）、コプロー

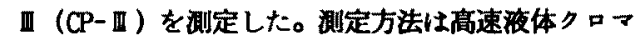
トグラフィーによった。同時に各種血庥生化学検査、 AFPを娜定し、TAEの治痖奻果をし、CIなどの画像診断 で判定した。

[成算] 尿中ボルフィリン体排泄はTAE後3-5日でビー クに達し7日目でほば旧值に復した。維コブロ(ICP) はTAE前值平均 $110 \pm 65$ 単位 $(\mu \mathrm{g} / \mathrm{g}$. crent.) で治瘄後 に230士93単位と約2倍に增加し、增加の主体はCP-】 であり前值60士45単位か５135士110単位之有意に增加 した $(P<0.001) 。 C P-I は 50 \pm 25$ 単位か.575士26単位 に增加した $(\mathrm{P}<0.01)$ 。UPおよびTPはTAE後に有意の 増加がみられたが（P(0.05）、6Pおよびロははとんど 変化がられなかった。尿中ボルフィリン体と各重血 液生化学梌㚗所見と比校するとAST、ALT、ALP、LOH $r$ ーGTPなどいずれる相関はみられなかった。一方血清 AFPとる相閶はみら九なかったか、APPが50\%以上の低 下群と50\%以下の低下群を比べると、前者でTAE後の TCPおよびCP-四が有意の高值を示した（P<0.01）。

[考察および結語]以上の成蜜からTAE後には尿中ポ ルフィリン6分画の5ちCP- II 、CP- I、UP、7P亜分画 の尿中排泄が增加し、7日間で前值に㞍ることが明ら かルなった。AFPの高度低下群に尿中ボルフィリン体 の非淤が多かったことを酧すると、尿中ボルフィリ ン体亜分画の㣜定はHCCKたけるTAEの早期治療效果判 定の指標になることが示㖟された。 
429 進行肝細胞癌に対する TAE併用PEIT 療法 の効果 一 TAE 単独㙩法との比较 一 中村三郎, 田中克明, 岡椅 博, 永瀨 遠藤 悠, 高邑裕太郎

（横浜市立大学医学部第三内科）

【目的】近年，肝細胞密に対する新しん治撩法の一つ として超音波がイド下経皮的エタノール注入療法（以下 PEIT)の有用性が報告されているが，その適虑江畽場 经 $3 \mathrm{~cm}$ 以下の小病変とされ，進行肝䋖胞癌に対しては PEIT単独で恨界があると指摘されている。最近我々 は進行肝細胞癌に対してる肝動脈塞栓療法 (以下TAE) とPEITを併用して良好な抗腫嫁効果加得られること

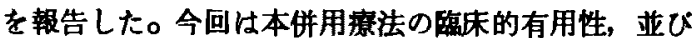
に適応につレて生存率及じ抗畽場効果の面よりTAE単 独療法と比較検討したので報告する。

【対象及び方法】1987年 1月以降当科にて肝細胞癌と 診断した店例中，原則として結節型て腫場侱 3個以下，

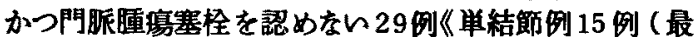
大腫瘍径 $2.0 \sim 8.2 \mathrm{~cm}$, 平均 $4.5 \mathrm{~cm}$ ), 2 3 結䬣例 14 例 (最大腫場径 $1.5 \sim 9.0 \mathrm{~cm}$, 平均 $4.7 \mathrm{~cm}$ ) 》 刘象にTAE 療法(ADR+Lip+スポンゼル)を施行し，2〜3週後よ りPEITを併用Lた(TAE+PEIT群)。PEIT施行回

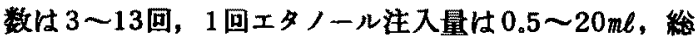
エタノール注入量 $11 \sim 120 m \ell て ゙ ち っ 。 1985$ 年以降当 科にてTAE単独療法を柂行した症例中 38例《単結節阙 13 例(最大畽歾徍 $1.2 \sim 8.0 \mathrm{~cm}$, 平均 $4.6 \mathrm{~cm}$ )，2 2 結

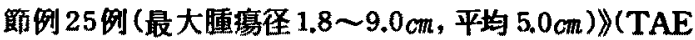

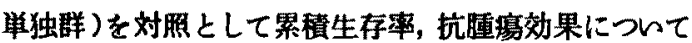
比梌討した。

【成樍 】(1) 単結節例の検討：腫場サイズの変化につい てはTAE+PEIT群では, PR 56.2\%, MR $18.8 \%$, NC $25 \%$, PD 0\%であり, TAE単独群のPR 17.3\%, MR 5.9\%，NC $58.9 \% ， P D 17.6 \%$ に比し有意差を認 めた。一年生存率は, TAE+PEIT群ては $100 \%$, T AE 単独群は 75\%であり, 累積生存曲線にて有意差を 認めた。 (2) $2 \sim 3$ 結節甽の娭討：腫場サイズの変化に つレては TAE+PEIT眻ては, PR 35.7\%, MR 14.3 $\%$, NC $35.7 \%$, PD 14.3\% てあり, TAE単独群のPR $21.7 \%$, MR $17.4 \%$, NC $21.7 \%$, PD $39.2 \%$ と比し 縮小傾向を認めるが有意差はなかった。

一年生存率て忏 TAE+PEIT眐 $100 \%$ ，TAE 単独 群 60\%であり，累積生存曲線にて有意差を認めた。

【結語】 TAEとPEITを併用することにより進行肝細 胞湯に奶してTAE単独群に比し高、抗腫韵効果と有意 の生存率の改善を認めた。本併用療法は結節型て睡場 径 $3 \mathrm{~cm}$ 以上の単発及び, 多発 ( 3 個以下) の進行肝細 胞癌の治療に㮴好有用な方法と考えられた。
430 転移性肝癌に対する肝切除後経門脈性りビオ

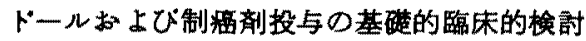

鈴木裕之, 宫崎 勝, 宇田川郁夫, 越川尚男。 鈑沼克博，伊藤 博，神野称生，海保 隆，木村文夫， 松本 閏，磯野敏夫，小山隆史，下田 司，中川宏治， 安蒜 聡, 林 伸一, 奥井勝二 （千葉大学医学部第一外科）

【目的】肝内の微小転移巣に対しては門脈血流の傢位 性が報告されており，肝切除後の残肝再発のコントロ ールとして経門脈性リビオドール(LP)および制程骩 投与が期待される。今回は経門脈性の L P ま上び制癌 郩投与の安全性に関し，ラットを用的基碳的検討を行

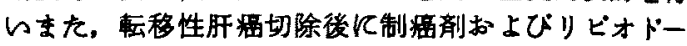
ル門脈内投与を行った症例につきそ安全性と有用性 を検討した。

【方法】1. 基硭的検討：Wistar 采雄性ラットを用的正 常肝及び68名部分切除媵の残存肝において門眽の幽門 枝上りカテーテルを門脈本幹へ㨉入留瞋し， L P $(0.2$. $0.5 \mathrm{ml} / \mathrm{kg}$ ), Aclacino mycin (ACL 1.3, 3.3mg $/ \mathrm{kg}$ ) 上びLP+ACL群とし門脈内注入した。測定愐目恃経 時的に血清 GOT, GPT, T-Bil 值, Aminopyrine demethyl ase 活性による肝マイクロゾーム機能棇量, ' $\mathrm{H}-$ Thymidine の訮 DNA への取り込みK上る DNA 合成能, 再生肝重量, ACL肝組織内浱度, 肝組織像お上び生存

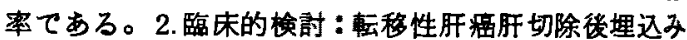
リザーバー付をカテーテルを門脈内と㨉入蜀置し, 街

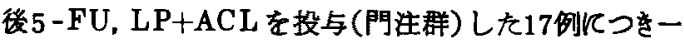
般肝機能，副作用お上びCT 像ての LPD停滞につ童娭

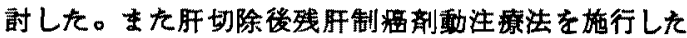
21 例(動注群) と門注群との間て再発率，予後の比䡬を 行った。

【成績】1. 基礎：正常訮にいては LP，ACL門脈内 投与の款管はGOT, GPT, T-BIL, 肝マイクロゾーム機 能総量とすと対照とした生食群と差畟を認好かった。 再生肝 DNA合成能性生食群に比し，LP群て約65\%, ACL群て約 50 万 と有意の抑制 $(\mathrm{p}<0.05)$ を認めるか， マイクロソーム機能総量の経過㤬, 生食群と明らか友 差異を認好回復した。Oil Red染色におらては再生 肝組織のLPの長期停滞が確認され，ACLお上びその 代謝痤物の肝組織内泿度仕, ACL 単独群飞比L,LP+ $A C L$ 群て有意《高值を示した $(p<0.05)$ 。2. 臨床: 所 切除後門注群は軽度の副作用を認也たが重第古合併应 は認めなかった。門注後GOT, GPT の整度の一過性 上昇を認め大以外，他の肝機能值に明らかな変動を認 めなかった。CTては残訮KLPO1 カ月以上の停滞 を認めた。残肝再発率恃非門注群の68\%に比し, 門注 群て壮 $17.6 \%$ と低的傾向を認め, 生存率て恃非門注群 の 1 年生存 $76.2 \%, 2$ 年生存 $44.0 \%$ K比較し門注群て

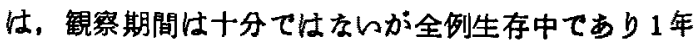
生存率仕 $100 \%$ と良好衣結果て西った。 
431

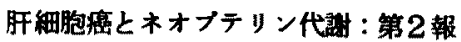

肝動脈塞栓術前绻の血中及び尿中ネオブテリンの亲動 とその臨床的意我

五代和䄫、大東恭子、山田貞子、上次郎、堀江 裕、 周防武昭、川崎宽中（鳥取大学第2内科）

\section{[目的］ネオブテリン（N）は分子昷䄪253のブテリ} ジン誘遷体でin vitroでは 数されマクロファージから放出される。近年Neはウイ ルス感染症、拒絶反応、AIDS、要性挭湯などで綀胞性 兔疫のマーカーとして用いられている。我々はさきに 本学会で永中Nを高速液体クロマトクラフィ一を用い

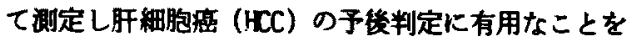
報告した。今回新しく開発されたRIA kitを用いてHCC の肝動脈塞拴術（TAE）前後で血中及び尿中Neを測定 乙興味ある成樭を得たのて埌告する。

[万法] 対象は、非切除肝緗胞秘（HCC）7例、正常者 70例。HCCTTAE前、TAE後1週以内、2週後に血清及び 层を採取し、IMU test Neopter in (FENING BERLIN GAMB製）のRIA kitを用いて測定した。同時に各種血 液生化学検㚗、AFPを測定した。またUS、CTなどの画 像倹㚗を行なってTAEの治䖒効果を判定した。

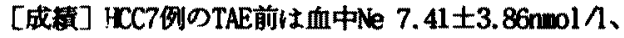
尿中Ne $334 \pm 183 \mu \mathrm{mol} / \mathrm{mol} \mathrm{Cr}$ であり正常対照の血中

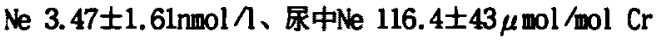
と此べて両者とも有意に上昇していた（p<0.05）。 TAE後1週以内に血中及び尿中Neはビークに達し尿中ビ 一クは血中ビークに2〜3日たくんて出現した。1週以

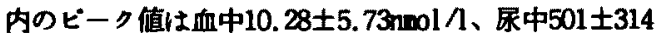
$\mu \mathrm{mol} / \mathrm{mol} \mathrm{Cr}$ で血中、尿中とるに前值に比べて有意 な上年を認めた（ $(00.05 ）$ 。2週後では血中及び尿中 Neと る下低下する佰向を証めた。血中及び尿中Neの変 和と各種血液生化学模㚗所見AST、ALT、LDH、CGT、血

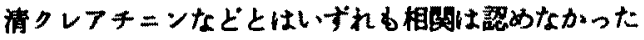
。さらK血清AFP、CRP及ひUUS、CT画像所見とも有意な 相既は認めなかった。

[結語] IMU test Neopterin kitを用いて血中、尿 中Nをを測定した結果HCCでは、血中及び尿中Ne忙正常 対照と比べて有意な上昇が㒛められることからら細胞性 兔度の充進が示惨された。またTAE前後で血中及び尿 中Neか有意に上昇したことからTAERより細胞性免疫 がさらに六進したすのと考えられた。以上の成㮦から

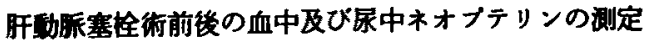

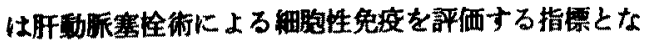
ることが示唆された。
432 健康成人にみられた散発性急性CMV肝炎例 の光顥的観察ならびにABC法に上るCMV抗原の棹出一 免度不全宿圭に発した例との対比

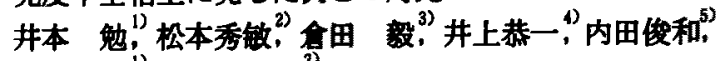
金子洋夫".

神戸神金病院内科, 同病理, ${ }^{2)}$ 国立予防荇生研究所病理

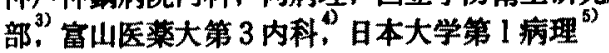

【目的】健康成人にみられた散発性急性CMV肝炎例に つき，病理組鐵学的検討を行なうとともに，免度不全 宿主に発した例と比較した。

【対象および方法】発应後15日以内に肝生検を実施し 得た健康成人の散発性急性CMV肝炎 8 侧と，免度不全 宿主に発し剖検にてCMNe因と診断し得た 4 例を対象 とした。散発例の血清学的䛦断には，CMVのCF, EAIgG，LA-IgG, MA-IgM抗体を用いた。肝組織につい ては，ホルマリン固定、バラフィン包埋後，薄切し， H一E染色およびAzan染色標本を作䌘した。また，倉 田およびBiogenex Laboratories の製造したCMV特 異ボリクロナール抗体をそれぞれ一次抗体としたABC 法にて、CMV抗原を検出した。

【成績】散発例の肝組機について，罗死の主たる様式 は種々の大きさの granulomatoid necrosisであ った。肝細胞のmitosis も殆どの例に観察された。類 洞内には単核紐胞の連珠状の浸潤が認められた。owl's eye と称される特有の核内封入体や肉芽睡はみられな かった。兔度不全摍主に発した例では, Councilman 体が散見されるものの，散発例の上うな特儌的な所見 にそしく，肉芽腫も存在しなかった。ただ，核内封入 体が少数の肝細胞に認められた。

$A B C$ 法による恰索では，散発例 8 例中 3 例の，一部 の肝細胞の，圭として絴胞質にCMV抗原が険出され， かかる肝細胞の周囲に単核細胞が集旗している所見も 認らられた。免度不全们では，多数の肝細胞の細胞質 および核内にCMV抗原が検出されたが，小葉内の浸湖 細胞に之しく，加，CMV抗原陽性肝緗胞と浸潤細胞 との間に関連性を見出だせなかっだ。

【結論】隹康成人に発した散発性急性CMV肝炎の組䋘 像は，肉芽畽の存在しない点を除けば，欧米の報告と おおむね一致していた。のV抗原について，欧米での 強出率は低いが，今回のシリーズでは 8 例中 3 例に検 出された。これは，生検時期が比較的早期であったこ とによると考えられる。いずれにせよ，比較的晚期現 象である owl's eyeはみられず, CMV辱染細胞は絧胞 性免度反応に上り敏速に破壊されるものと推定された。 これに対し，兔度不全の宿主に発した例の肝障害は。 主としてCMV自体の直接的な肝細胞破塤作用によるも のと想定された。 
ルス感染症

新生児・乳児期肝疾患とサイトメガロウイ

田沢雄作 (秋田大学小肾科)

今野多助（東北大学附属抗酸菌研究所小児科）

【目的】サイトメカロウイルス (CMV) 感染による 新生児・乳坚期䠦床像の多粎性は周知の事実であるが， 同時期に認められる各程肝疾患，肝機能異常との関連 についての研究は数少ない。我々はこれら患児を対象 とし，血清抗 CMV 特異抗体を指標として CMV 感染 との関連性について検討し，知見を得たのて埌告する。 【方法】新生児・乳児期 (月令 4 ケ月以下) に肝疾患 旰機能異常か認められたA 群 : 胆道閒鎖症 (A 1，20 例) 新生肾肝炎症侯群 (A 2，33例)，非黄㡺性肝炎 (A 3，6 例), 肝脾腫 (A 4，9 例), 対照群 (144例), B群 : 下気道炎・肝機能異常合併孚児 (B 1，8 例), 非合併乳児 (B 2，66例)，下気道炎・肝機能異常合 併低出生体重児 (B 3，７列)，非合併低出生体重坚 （B 4，8例)，対照群 (34例) を対象とした。血清中 抗 CMV 特異抗体, IgG early antigen (IgG EA), IgM membrane antigen (IgM MA) の測定は既報の 方法にて施行した (Numazaki et al., 1980)。IgG EA, IgM MA は共に 8 倍希积以上を陽性とした。A 2 群 では肝機能異常重㫌度之，B 3，B 4 群では翰血歴と 血清 CMV 特異抗体值との関連性についてむ検討した。 【成糟】A群：1）IgG EA の晹性率 その幾何学的 平均希积倍数値 (GMT) は各々, A 1 (20\%, 12.0), A $2(60 \%, 34.4)$, A $3(66 \%, 48.0)$, A 4 (55\%, 51.2), 対照群 (18\%, 13.2), IgM MA の各々はA 1 $(5 \%, 8.0)$, A $2(24 \%, 13.0)$, A $3(50 \%, 16.0)$, A 4 （55\%，40.0)，対照群 $(0.6 \% ， 8.0)$ を示した。 2) 新生児肝炎症候群 (A 2) の抗 CMV 特異抗体価 高值例 $(\mathrm{n}=5: \operatorname{IgG~EA}, \geqq 1: 32$ 又はIgM MA, $\geqq$ $1: 8)$ では, 低值例 $(n=7:$ IgG EA, $\leqq 1: 8$ および IgM MA，（1：8）に比較し血清 GPT 值の 低值を認めた $(168 \pm 93$ vs $84 \pm 63)$ 。B群 : 1$) \mathrm{IgG}$ EA の晹性率，その GMT は各々， B 1 (75\%, 42.6), В $2(37 \%, 30.7)$, В $3(57 \%, 40.0)$, В $4(37 \%$, $64.0)$, 対照群 (32\%, 20.1), IgM MAの各々はB 1 $(37 \%, 42.6)$ В $2(4.5 \%, 10.6)$, В $3(42 \%, 10.6)$, B 4 (25\%，12.0), 対照群 $(1.3 \%, 8.0)$ を示した。

2) B 3，B 4 両群て血清抗 CMV 特異抗体高值 (IgG

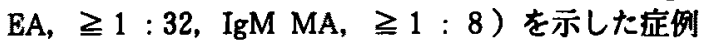
中, 輸血歴は各々 $3 / 4,3 / 3$ 合計 7 例中 6 例に認めら れた。

【結論】新生児・乳児期所知患, 肝機能異常と CMV 感染との関連性，とくに新生児肝炎症候群，非黄疸性 旰炎，病因不明の肝脾腫、下気道炎䍜患時肝機能異常 例との関連性が明らかにされたほか，低出生体重児に 多用されている輸血と CMV 感染との関連性が示唆さ れた。

434 自己免度性肝炎発症に関するHLA抗原の解折 一 特に疾患感受性に関与するDR 4 サブタイプの分子生 物学的娭討 -

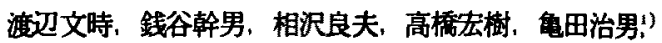
猪子英俊，辻 公美 ${ }^{2}$ ( 東京忽恵会医科大学第一内科)， 東海大学移植学 ${ }^{2)}$ )

【目的】ルポイド肝炎およびその数緑疾患の発症には进伀 的素因にもとつく免疫異常か認められるととから. HLA 抗原の解析がなされている。その結果本邦ではHLA-A 26,DR4 との関連力認められているが，本症の発症に関立 ろてれら抗原の分子生物学的意義は明らかではない。今回 我々は自己免疫性肝炎の远伝学的背景を再娭討すると共伿, DR抗原のDWサブタイプをDNA typingにより解析し た結果、本症の発症に関与すると考えられるエピトープを 推定し得たので報告する。【方法 】厚生省の自己免度性䄯 炎診断基篗に基ついたルポイト肝炎 3例およびその颣緑疾 患 3 例の計 6 例を対象とし，以下の方法によりHLA.DN A typing を施行検討した。HLA䡃性頻度の対照群とし ては正常日本人 340 例を用いた。 HLA typingは。

Terasaki らのmicrocy totoxicity法により行い, HLA-A，B，CおよびHLA-DR，DQ抗原の出頹度

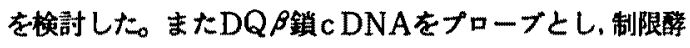
素Eco RI. Pst I. Taq I, Msp I を用いたSouthern blot hybridization Kよb. Dw type specific ンドを検出しDwサブタイブの判定を行った。【結果】対 照群と疾患群のHLA出現頻度を $\chi^{2}$ 検定により比較したと ころHLA-B35，B39，DR 4 加有意江增加し，特にDR4 は疾患群 6 例全例晹性であった。また複数抗原では 35 -DR 4-DQw 3 関連抗原加対照に比へ有意に増加して おり， $x^{\mathbf{2}}$ 值むてれらの抗原の同時存在に従い増加してい た。疾患群 6 例中 5 例䎲ついてDR 4 抗原のDWサブタ1 プを検討したとてろ，2例にDR 4/Dw 4，3例にDR 4 /Dw 15 を認めたが, DR 4 / Dw 10 およびDR 4/Dw 13は存在しなかった。【結語】今回の検討では，HLA -B35, B39, DR 4 およびB 35-DR 4-DQw 3 関連抗 原と本疾患との関連が示された。とのうちDR 4抗原は疾 患群全例江認められ，疾患感受性に最も強く関与している あのと考えられた。さらにてのDR4のDWサブタイプは， Dw 4 およびDw15亿限定されていた。ヒトゲイム中のDR $\beta$ 遗伝子上で 70-74 翻のアミノ酸をコードする塩基配列

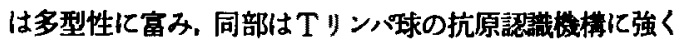
関与している。との領域のアミノ酸已列はDw 4ではGlu-Lys -Arg-Ala-Ala であり. Dw15 ではGlu-Arg-Arg-AlaAla で両者の極性や電荷はきわめて類似しているか，Dw10， Dw13は極性や䉓荷に影䇺するアミ/酸置換か存在する。従 って. DR $\beta$ 銷の 70-74番目のアミ/酸配列力s本症の発症に 重要な役割を果たしているものと考えられた。おお，慢性関節 リゥマチの発症においても同部のアミノ酸配列の関与力報 告され，両疾患の発后機序の類似性が示唆された。 
$\gamma$-interferon に上る HLA class I 抗原

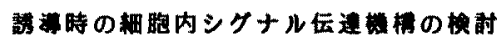

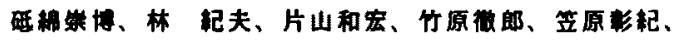

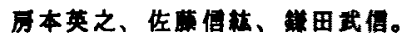

(大阪大学第一内科)

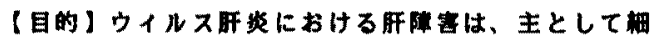
盷性兔疫に起因すると考えられており、宿主兔度店

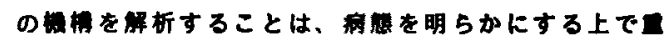

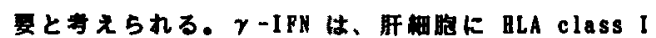

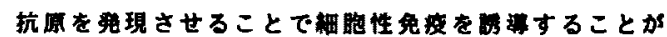

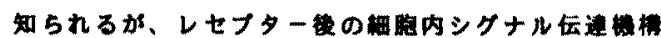
についての模时は行われていない。そこで、 hepatoblaston cell line である 四ub-6 を用い、 $r$-IPNに

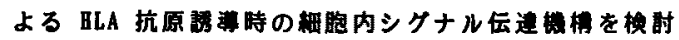
した.

【方法】 hepatoblastoma cell lineである 日uh-6 を、 $\gamma$-IPN 存在下で 10X PCS 潾加の Dulbecco's Eagle

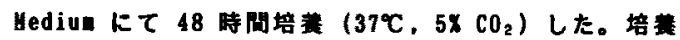

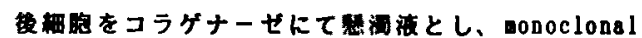
anti-HLA class I antibody $E \tau 4^{\circ} \mathrm{C} 30$ 亦反度後、

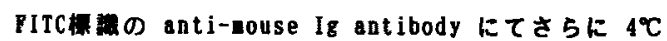
30 分反応させ、PACScan にて HLA の発現を解析した。 さらに、, $\gamma$-IFN 存在下に H-7(PKC inhibitor), H-7 (calmodulin antagonist), E-8(protein kinase A inhibitor). PMA(PKC activator), dbcAMP(cAHP analog). EGTA, A23187(calciun ionophore)を泇し、

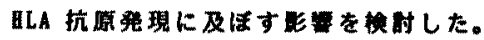

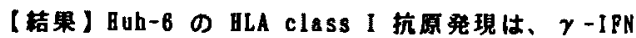

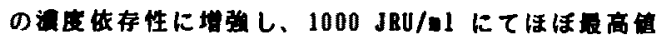

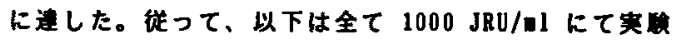
を行った。 $\gamma$-IPNによる 日LA 抗原叒現は、日-7によ

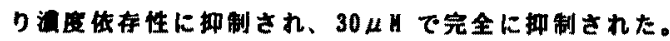

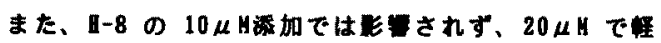

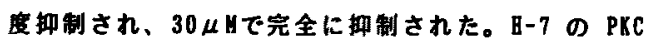
に对する【i は $6 \mu \mathrm{M}$ ，protein kinase $A$ に对する

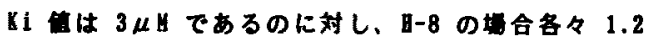
$\mu M(P X C) 、 15 \mu H$ (protein kinase A) であり、 $\gamma$-IFN による 昛A 抗原器は、PKC の系を介していることか 明かとなった。さらた、PKC activator である PHA 加により $\boldsymbol{\gamma}$-IPN 存在下及ひ非在下で、昛A 杭原の

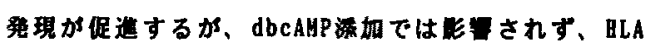

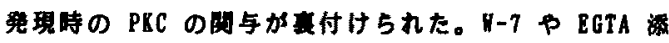

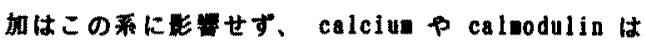
昛A 抗原の唚現に阐与しなかった。

(結原) 日uh-6において $\gamma$-IPNによる HLA class I 抗原発现のホストレセフター耕盷内シクナル层逢には，

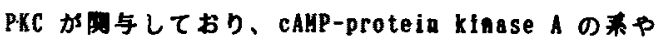

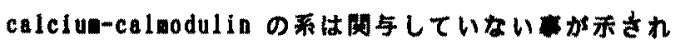
た。
436

缩主絧胞の H L A Class I抗原表出および

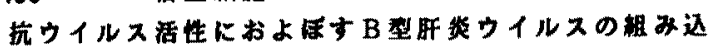
み. 独の影

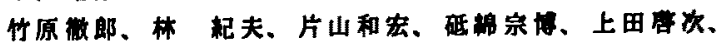

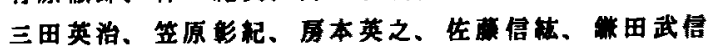
[大阪大学第一内科)

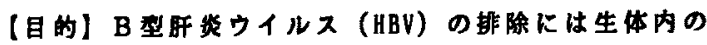
インターフェロン (IPN) システムが閳与している。

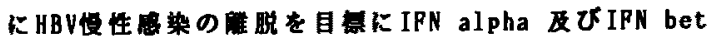

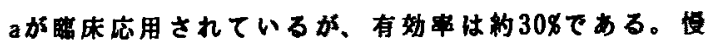

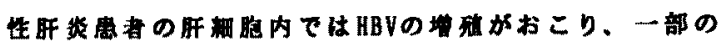

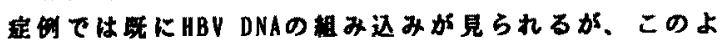
うな旰满胞に对し内在性あるいは外来性に投与された IPNがとの居度有効に作用し得るかは明かではない。モ こで我くは、Huh6 (hepatoblastona cell line)に了 copyのHBV DNAをtransfectionし られたHBV DNA持堂

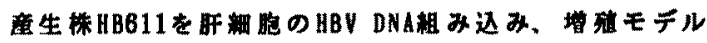

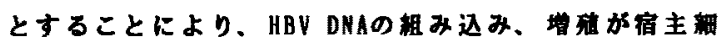

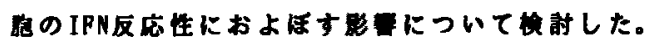

【方法】1)桷胞表面 H L A class I抗原：Huh6. HB6 11を各 IPN (rIPN alpha, nIPN beta, rIPN gamaa)

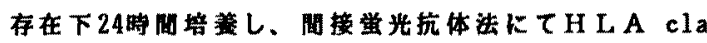

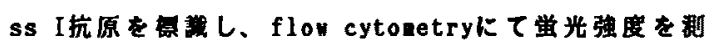
定した。2)抗ウイルス活性：Huh6およびHB611の抗ウイ

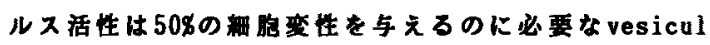
ar stonatitis virus (VSV)の諘度で洒した。また

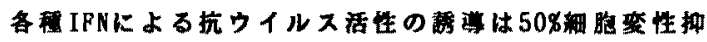

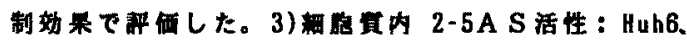

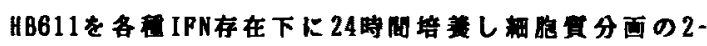
$5 \mathrm{AS}$ 活性を测定した。

(成辕) 1)HB611はHuh6K比しH L A class I抗原密度 が高く、またIPN alpha、IPN beta、IPN gannakより

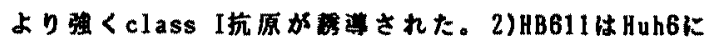

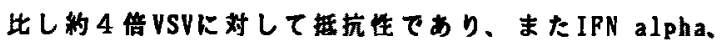

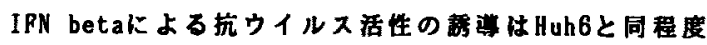
に琶められた。3)HB611はHuh6に比し2-5A S 活性が高 く、IPN alpha、IPN betakより、より强く2-5A S 活 性が䴔酔された。

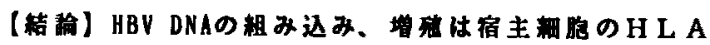

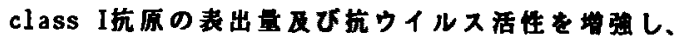
また、IPN alpha、IPN beta. IPN gamak $よ る \mathrm{class}$ I 抗原の敖尊、IPN alpha、IPN betakよる抗ウイルス

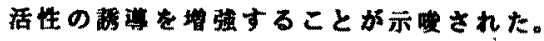


「目的」非 A 非 B 型優性肝炎 (CH-NANB) 症列における インターロイキン2(IL-2)カスケートの间与を明確に するために、CH一NANB 急者リンバ球のIL-2に対する反 応性、IL-2レセブター檑性細胞数 (IL-2R)、IL-2産生 能について㛟討した。

「方法」CH-HANB 21症例（平均年弇 44.7才） を対象 とし、コントロール群として健常者11例（平均年跲

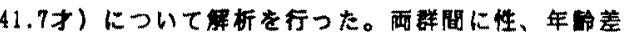

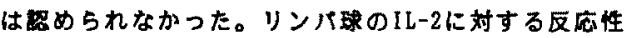
は、末血より阝icoll-conray 法により $5 \times 10^{5}$ のリン

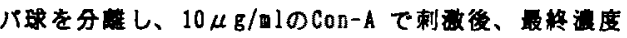
$50 \mathrm{U} /$ ml のrIL-2 を加え、 ${ }^{3}$ 日-Thyuidineの取り込みの 差より揤定した。IL-2R の䉼定については、リンバ球

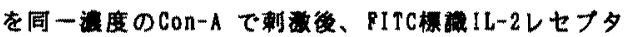
一抗体と反応させ、flowcytoneter により解析した。 リンパ球のIL-2産生能は、リンバ球を包乘後、Con-A

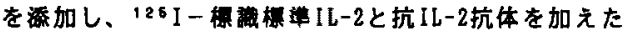
2 抗体法により算出した。さらに、CH-NANB 症例では、 抗HCV 抗体娜定をEIA 法 (Chiron社)で行った。

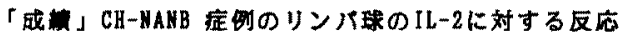

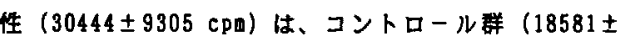
$6852 \mathrm{cpm})$ に比爪、有㚇に上昇を示した $(P<0.05)$ 。ま た、CH-NAKB症例をGPT 100 U/L以上の高值群 $(n=10)$ と 100 末满の低值群 $(n=11)$ の2群に分け解析したところ、

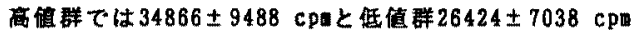

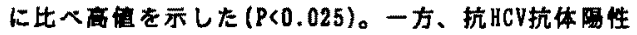
群は10例势められたか、、抗HCV抗体院性群に比へて有 意な差は园塞されなかった。IL-2レセブター隄性細胞 数の検討では、CH-MANB 急者 $(49.6 \pm 12.8$ x)とコント ロール群 $(51.1 \pm 8.2$ タ) の画者に明らかな善はみられ

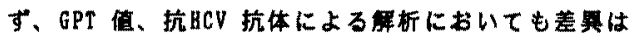
路められなかった。IL-2産生能は、男性の抗HCV 抗体 陽性群 $(18.3 \pm 7.1 \mathrm{U} / \mathrm{al})$ においてコントロール群

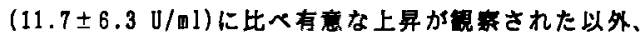
群间に有意差は喔められなかった。

「結語」CH-NANB 惫者リンパ球のIL-2に対する反応性

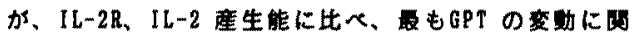
連していることが示された。また、今回の模时で、抗

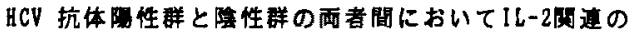
免疼的な差は明らかではなかった。

438 影稞 マウス実医的肝资における新生期胸腺揞出の

外田一成，渡辺恭行，小松晃一，中西敏夫，榐山梧朗” 池本吉博 ${ }^{2}$ (仏島大学第一内科"，厷島赤十字病院内科”)

【目的】我々は，新生期胸腺摘出（NTx）により， 、 ウス自己免疫性肝炎が增強しより要延化するとと，ま

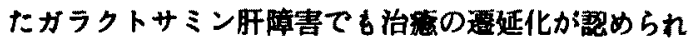
るととを示してきだ。今回NTxによるT細胞機能不全か， Propionibacterium acnes(P.acnes) llipopolysaccharide

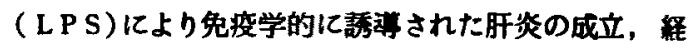
過にいかなろ影雾を与えるか検討した。【万法】8週 踚の正常 A/J mice (A 群)と出生後2 日から3 日の間に 胸腺摘出したA/Jmice (B群)において尾静脈より，1吗 のP.acnes 静注し， 7 日後に $0.05 \mu \mathrm{g}$ のLPS を追加 静注し肝炎モデルを作製した。而群のLPS 静注後 24 時間以内の致死率，LPS 静注 1 日，1 週，1 カ月，3力 月後の肝組維像，血清ALT值，抗LSP 抗体価を模詂 した。【成續】1）LPS静注後24時間以内の致死率は A 群83匹中10匹 (12.0\%), B 群106匹中12匹 (11.3\%) と差がなかった。22)肝組㼄像は，LPS 静注 1 日挠て

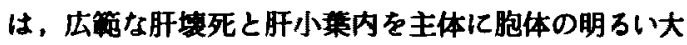

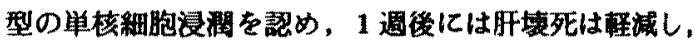
門脈域に大型の単核細胞の他に一部小型の単核細胞浸 洞を認め, 両群間に差異は認められなかった。慢性期 には小葉内の変化は両群とも蛏減した。一方, 門眽域 の変化については，B群では限界板の破壊を伴う小型

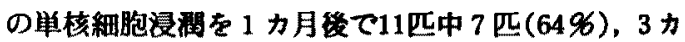
月後で23匹中6匹(26\%),またA群ては1カ月後14匹中 4 匹(29\%)，3カ月後13匹中0匹( 0\%)に跁め, B 群はA 群に比し高率であり,より強い門眽域の変化を㒛めた。 3）血清A L T 值はA群ではLPS静注後 1日，1週，1力

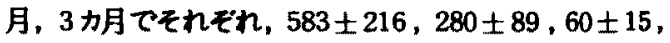
$49 \pm 19$ ，またB群で $582 \pm 437 ， 434 \pm 344 ， 103 \pm 35$, $60 \pm 38$ であり急性期に差はなかったが、1 カ月後てはB 群はA群に比し有意に高值 $(p<0.01)$ でっった。 4 ) 抗 LSP抗体価 (OD值)は，A群ではLPS静注後 1 日，1

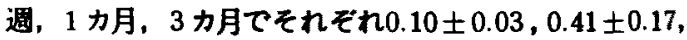
$0.41 \pm 0.20,0.26 \pm 0.10$ ，またB群では $0.22 \pm 0.19$, $0.73 \pm 0.35,0.62 \pm 0.27,0.51 \pm 0.26$ であり, 両群とる LPS 静注後 1 週以降で陽性であったが，B群はA群 に比し有意に高値 ( $p<0.01)$ であった。【結語】1)画 群間に，LPS 静注後 24 時間以内の致死华，急性期の

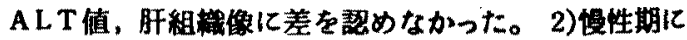
は，B群はA 群に比し，ALT值の高值，抗LSP 抗体

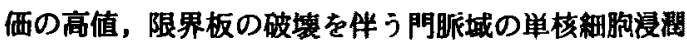
を高率に認めた。この慢性期の肝障害は急性期と異な り L S P 分画に感作されるためであると思われ，新生 期胸腺摘出によるサプレッサー機能の低下が俊性期の 肝障害に関与しているととが示兴された。 
439 シナナマイド(cyanamide)によるアルコール 性肝線維症, ととに型コラーゲン形成の促進 細胞培盖による検討

鱼谷蜞与隆, 緒方晴彦 (都立広尾病院内科)，岡䗁鮌

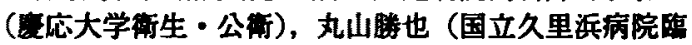
床研究部), 芹沢宏, 重田洋介, 織田正也, 石井裕正, 土座雅春（缶応大学消化器内科）

【目的】アルコール性肝既害に㖊められる肝細胞周囲 性線維化の部には間葉系緭盷の增生がほとんど認めら れないことが多いととから肝細盷自体がコラーゲンを 産生する可能性が考えられる。ADH, ALDH の存在か

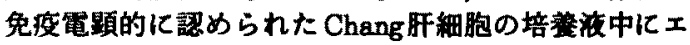
タノールおるいはアセトアルデヒドを添加するとChang 肝細胞のコラーゲン合成能が誘導されるととを報告し てきた。ALDHの阻害郕として知られるシアナマイド とェタノールの同時添加では，エタノール単独投与の 埧合よりも線維形成が䒕進するととが推测されるのて， との点につき検討した。【材料およひ方法】1)形悲学 的検討 : Chang 肝細胞を Falcon plastic 細胞培窇管を 用い，下記の培盖液中にて培盖。1) Eagle's MEM+12 96 FCS + ascorbate $(50 \mu \mathrm{g} / \mathrm{ml})$ (標準液)， ii) 標準液 $+\mathrm{EtOH}(100 \mathrm{mM})$, iii) 標集液 + Ac-CHO (200 $\mu \mathrm{M})$, iv) 標準液 + EtOH (100 mM) + cyanamide (0.3 mM), v) 標準液 + cyanamide $(0.3 \mathrm{mM})$ 。各50検体宛を 28 日 間培美。好銀線維の有無を光顥的に镜察。さらに I 型 およひ埴型コラーゲン同定のための免度電影ならびに 組䋘化学的検查を施行。2)培美液中の III 型 procollagen aminopeptide (P-II-P) 源度の测定 : EtOH, cyanamide, EtOH + cyanamide をそれぞれ添加した無血清培 養液中で Chang 肝細胞を 3 日間培盖し, 各検体の培善 液中の $\mathrm{P}-\mathrm{II}-\mathrm{P}$ 量を Hoechst 社の RIA キットを用い Rohde らの方法に従い湘定。【成嚗】標準培㧔液中に エタノールを添加した群で16\%に，アセトアルデヒ トの群では10\%に，エタノールにシアナマイドを併せ 加えた場合には6096に好銀線維の形成が語められた。 好鑹線維は電顥的にはコラーゲン線維束からなり，免 度組織化学的, 免度電影的には而型コラーゲンであっ

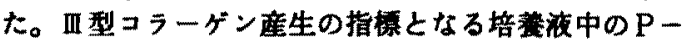
IIIーP はエタノールのみの群に比べ, エタノールとシ アナマイドを同時添加した群では高值を示した。【結 諭】1)Chang 肝細胞の培美液中にエタノールを添加す るととにより，肝細胞によるコラーゲンの産生が誘会 されるととがある。ェタノールとシアナマイドの同時 添加で，線維の形成が促進される。シテナマイドによ り肝細胞の ALDHー】が阻害され，アセトアルデヒド が渵積するととがその一因と推测される。2) Chang肝 細胞により産生されるコラーゲン線維は III型コラーゲ ンが主体を占める。
440 肝疾患における7Sコラータ゚ンと N 型コラーゲ ンの筫的。量的差異につい下

中山一, 山内固義, 水原裕治, 大畑充, 平川漳一, 中島尚登, 中原正婎, 北原敏久。 藤讯湖，渑田治男 （東京慜恵会医科大学第 1 内科）

【目的】最近、血清中のコラーダン関連物質の湘定が可 能となり、肝線維化の血清学的指骠として注目されて いる。とくに基底膜成分の川型コラータ゚ンは臨床的に高 い評価がされている。そのN末端側の7Sドィインは7S コラーダンとも呼ばれ、THドィイン, NC1ドィインとと もに四型コラーダンを構成している。しかし、各ドィイ ンは異なる代謝をする可能性し考えられる。演者らは N型コラーダンの2つの测定法，即ち7Sの抗体を用いた 测定法 (7S コラーダン・以下 7S) と、7SとTHの 2 抗体サ ント゚イッチによる测定法（W型コラータ゚ン・以下 $\mathbb{N c}$ )そ用い て、臨末的意義の美異、ダルろ過法を用いた血中存在様式 の差異およひ肝組織内の局在を検討し、両者を比较した。 【対象および方法】(1)健常者58例と肝疾患患者76例を対

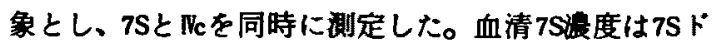
ハインに対する polyclonal抗体を用いたRIA法(日本DPC) て、血清Nc源度は7Sドィイと THドメインの2抗体(monoclonal抗体)によるサンドイッチ法を用いたEIA法（富士 薬品)て測定した。(2)血中の存在様式を Sephacryl S-400 を用いたゲルろ過法て、健常者および肝疾患患者血清を 検討した。(3)肝組織内局在について、7S浱度の貺定に 用いた polyclonal抗体と Wc 港度の測定に用いた7Sに対す る monoclonal抗体で間接抗体法により検討した。 【成程】(1)健常者の血清 $7 \mathrm{~S}$ 灌度およびNc浱度の平均 +2 SDはそれぞれ $5.0 \mathrm{ng} / \mathrm{ml} .140 \mathrm{ng} / \mathrm{ml}$ ありり、これらを正常 上限とした。肝疾患では、両者としに高值をとり、両 者仙急性肝炎 $\mathrm{r}=0.75(\mathrm{p}<0.05)$, アルコール性肝倩害 $\mathrm{r}=$ $0.94(\mathrm{p}<0.01)$ て正相関がみられた。しかし、慢性肝焱、 旰硬変、肝癌ては推計学的な関係はみられなかった。 た、肝疾患における異常率は、7S/Ncのそれぞ秎が急性 肝炎 7例中て7 7例 $(100 \%) / 3$ 例 $(42.9 \%)$ ，慢性肝炎 19例中 18 例 $(94.7 \%) / 11$ 例 $(57.9 \%)$. 肝硬変 18 例中18例 $(100 \%) /$ 12例 $(66.7 \%)$ ，フルコール性肝障害11 例中 8例 (72.7\%)/ 6例 $(54.5 \%)$, 肝癌 21 例中 19 例 $(90.5 \%) / 18$ 例 $(85.7 \%$ ) が 異常を示し、急性肝炎、慢性肝炎、肝硬変において差 がみられ（各々p<0.05)いずれも7Sか高率であった。(2) その血中存在様式は健常者、䀒疾患においてWcはい゙ れ6分子量65万に一致しだつのビークを認めたのに 対し、7Sではより高分子領域に3峰性のビークが認 められた。(3)組織内局在についてはともに間質結合織 と類洞周用に染色を認めた。

【結語】肝疾患において7SがN゙よりも異常率が高く臨床 上の有用性か沶唆された。しかも、7SとNcは慢性肝炎て相

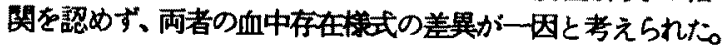


子多粎性ー7Sコラーグンを中心にしてー

山田貞子, 周防武昭, 岸本洋輔, 章壁由香, 村脇義和 ，長谷川真弓，川崎宽中、・吉川典萃

(鳥取大学第二内科, ・日本DPC コーポレーション)

【目的】我々はすでに血清中のヒドロキシブロリン含 有ベブチドならびにブロコラーダン而ベブチドを分析 し、それらに分子多样性があり愠性肝疾患で特翼的に 增加する分画のある事を報告して来た（Eur.J.Clin. Invest. 1983 、医学のあゆみ.1986)。今回さらに血 清中のN型コラーゲンとくに7Sドメイン（7Sコラーゲ ン）に注目して分析を行ない、肝患でのIV型コラー ゲンの血中動態を模討したのでその成嚗を報告する。

【方法】対象は急性肝炎 (AH) 28(例、慢性非活動性肝炎 (CIH) 16例、慢性活娌性肝炎 (CAH) 25例、肝硬変 (LC) 53例、肝硬变合併肝細胞等 (HCC) 30例であり健康成人 30例を对照とした。「型コラーゲンはヒ卜胎盤より 精製し、紐菌性コラゲナーゼ消化により75コラーゲン を得た。 N 型コラーゲンでウサギを免度し、7Sבラ ーゲンに特異性の高いpolyclonal抗体でRIA 法を確立 した。次に血清をSephacryl S-400HR (2.6 $\psi \times 40 \mathrm{~cm}$ ）に供し、リン酸buffer (pH 7.2) で溶出、各フラクシ ヨンの7Sコラーダン量をRIA で荆定しIV型コラーダン の存在バターンを棈討した。

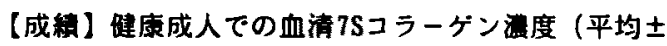

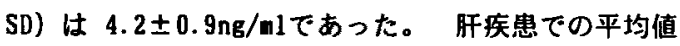
はАH: $5.1 \pm 2.0$ 、 СIH: $6.5 \pm 2.5$ 、 САH: $9.5 \pm 3.8$ 、

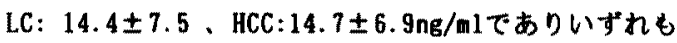
有意に增加した。血清をゲル渵過すると健康成人で は7Sコラーゲンに一致したビーク (フラクションII） それより高分子領域に大きなビーク(フラクション I )また低分子領域に1〜2のビーク（フラクションII ）が存在した。各フラクションの型コラーゲン湿 度は健廣成人血消1目1 あたり7SコラーゲンとしてI：

1.9ng 、II :1.0ng、III :1.0ngであり48\%は7Sコラーゲ ンより高分子であった。CIH では血清 $1 \mathrm{ml}$ あたり I $: 5.3 \mathrm{ng} 、$ II $: 1.4 \mathrm{ng}$ 、III:0.2ng、CAH では I $: 6.5 \mathrm{ng}$ 、II :1.9ng、III:0.2ng、LCでは I : 14. 1ng、II :2.6ng、III :0.2ngであった。显原成人に比べ慣性肝疾患では高 分子フラクションの增加が大きく、LCでは血清浱度の 80\%にも達した。 また血清7Sコラーゲン值とフラク ションIは $r=+0.989$ 、II は $r=+0.722$ と有意の相関を示 し（各々p<0.01）、II とは $r=-0.032$ 相関であった。 【結論】血清中の「型コラーダンには分子多様性があ り、显性肝疾患では主に7Sコラーゲンより高分子のコ ラーゲンが血清中に增加する事か明らかになった。

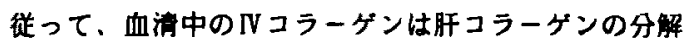
系よりむしろ合成系をより反映する可能性が推测され ろ.

442 生化学的分析

肝疾患における肝組維内、型コラーゲンの

周防武昭，山田自子，岸本洋读，河野通盛，星野潮， 長谷川真弓，沢田博明，新美百合子，加藤誠一， 堀江裕。川崎蒬中, “吉川典孝

(鳥取大学第二内科、日本DPC コーポレーション)

【目的】最近、われわれは各㮔肝疾患において血清中 のIN型コラーゲンの7Sドメイン（以下7S）を测定し、 肝線維化の血清マーカーとして有用であることを報告 した。今回、血清7Sは肝におけるN型コラーゲンの 分解系、合成系のどちらを反映するのかをみるために 肝組織中の7Sをコラゲナーゼ処理前後で分析するとと もに、血中7Sとの関連を阵討したので報告する。

【方法】正常者 3 例。慢性非活動性肝炎 (CIH) 8例、慢 性活動性肝炎 (CAH) 8例、肝硬変 (LC)8 例を封象とした

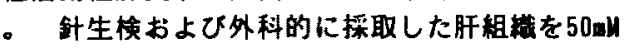
Tris-HC1維衙液(pH 7.4) とともにホモシネート後、 15,000g、15分間遠心し上清をえた。つきに沈殷物 を細菌性コラダナーゼ $(1: 100) 、 0.2 \mathrm{M} \mathrm{NaCl} 、 0.002 \mathrm{U}$ $\mathrm{CaCl}_{2}$ を含むTris-HC1縓衙液と37·C、24時間インキュ ペートしたのち上清をえた。各上清ならびに血清中 の7Sをヒト胎盤より精製した7Sに対するpolyclonal抗 体を用いたRIA 法にて溂定した。さらにSephadex S -400 HR にてゲル娍㟫し各分画の7Sを测定した。

【成績】肝ホモジネート上清中の7Sは正常者で平均 1.0ng/mg/liverであり、CIH では差がなかったがCAH で2 倍、LCで3.8 倍と段階的に有意に增加した。肝 コラダナーゼ処理上清中の7Sは正常者で平均13.6ng/ mg/liverであったが、CIH 1.5 倍、CAH 2.4 倍、LC 1.9 倍といずれも有意に增加した。血清75濃度は肝 疾患で段階的に有意の增加がられ、肝コラゲナーゼ 爸理上清7Sとは関連がなかったが、肝ホモジネート上 清7Sと $\mathrm{r}=+0.660$ と有意の相関を示した。一方、ゲル 浦造をすると、正常者、肝疾患とも肝コラゲナーぜ姏 理上清7Sは7S分子に一致して存在し、肝ホモジネート 上清7Sは7Sより高分子分画か大部分を占めた。血清 のダル㨁過では正常者は7S分画、高分子分画、低分子

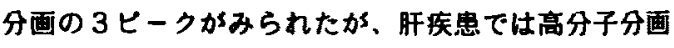
か大部分を占めた。

【結訜】血清7S抗原はN型コラーゲンの分解あるいは 新たに合成され組被に沈着していない型コラーゲン を反映すると考えられる。今回の成綁で、血清7S岋 肝ホモジネート上海7Sと相関し、ゲル泪にて血清。 肝木モジネート上清とも离分子分画か肝疾患で大部分 を占めた。したかっって、血清7Sは肝におけるI型コ ラーゲンの合成系をより反映することが推測される。 
443 アルコール性肝硬変症における基底膜コラー ゲンの産生と分解

丸山勝也，岡渏 愁*，高木俊和，奥山㫃二，高木 敏， 石井㭲正"*，土屋雅春"*

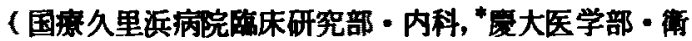
生公臬衛生, ${ }^{* *}$ 晨大医学部・消化器内科）

【目的】私共壮肝硬变症の成因の拣序の一つに，肝に おけるIV型コラーゲン分解䣼活性の低下か関与して レる成績を示してをた。今回はアルコール性肝硬変应 におけるコラーゲン代謝の特異性について, 合成面とし て血清中のIV型コラーグンの渆定とその heterogeneity につんて模索し，分解面としてIV型コラーゲンに特異 的に多く含まれる 3-hydroxyproline (3-HYP)の尿 中基碳排泄量を測定することにより倹討を行った。

【対象および方法】肝硬変㱏23例の血清IV型コラーゲ

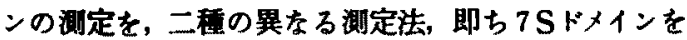
抗原としたボリクロナール抗体を使用した RIAキット (7S-RIA)と，7Sドメインかよび非 $7 \mathrm{~S}$ 非NC-1 部分 を抗原としたサンドイッ手法によるEIAキット(IV-EIA) により行った。また7S抗体に反応する血中のheterogeneityにつんて, 血清を Sephacryl S-400HRカラ ムを用いたHPLCにて分画し，各分画を7S-RIAにて 测定し検討した。また10列の尿中3-HYP の基碳排泄 量をアミ，㬐分析機を用々て测定した。スタンダードと なる 3-HYPはSzymanoviczらの方法により Delonix Regiaの種子より抽出し精製した。

【結果】アルコール性肝硬変应の 23列の血清7SRIA 值およびIV-EIA值は健常人のそれに比し有意な高値を示

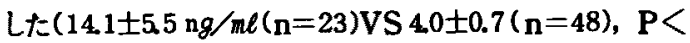
0.001 および $421 \pm 238 \mathrm{ng} / m \ell(n=23)$ VS $80 \pm 20(n=47)$, $\mathbf{P}<0.001$ )。また肝生検を施行したアルコール性肝疾患 全体 $(n=102)$ ては肝線維化の程度とIV型コラーゲン值と

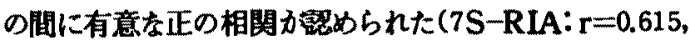
IV-EIA： $r=0.504, P<0.001)_{0}$ 䀒硬変症血清中のIV型二 ラーゲンの heterogeneity の検索では, 健常人に比し standardの分子量よりる大をな分画にピークがみられ た。一方旰硬変症列の尿中3-HYP量は, 健常人に比し 有意に低下していた $\left(0.047 \pm 0.016,3-\mathrm{HYP} / \mathrm{CRNN}^{-2}\right.$ $(n=10)$ VS $0.060 \pm 0.020(n=94), P<0.02)$ 。

【結論】アルコール性肝硬変㱏において，1. 血清IV型 コラーゲンが高值を示し，また heterogeneity の倹索 で7Sよりる大きな分画にピークがみられたことは，血 中のIV型コラーダン值は基底獏コラーゲンの分解を示 ナஆのでく合成の艺進を示すると推測された。2 既 に抜告した肝のIV型コラーゲン分解醭素活性の低下と， 今回の尿中 3-HYP 量の低下ょり, 基底膜コラーゲン の分解の低下があることが推測された。

今後血清 7S-R IA と烁中 3-HYP を測定することによ

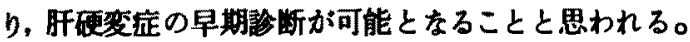

444

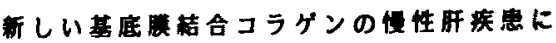

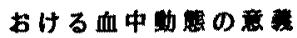

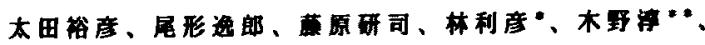
吉田四*

(更京大学第一内科、同数黄学部化学・、贯生堂基磁科 学研究所・的

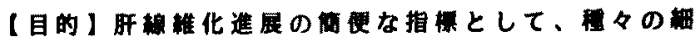
胞外マトリックス成分の血中㴬定が行われているが、 造展度を的霍に反映するものは末たない。我々は、七 卜血笛の基底展に存在する新しい基底落結合コラゲン （B B C）を見出した。これは、I型コラグン $\alpha$ 銷と

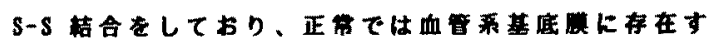

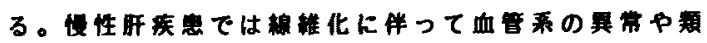
洞内の基底罢の異常增生がられることから、これが、

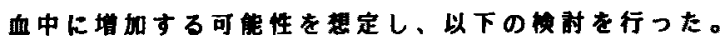

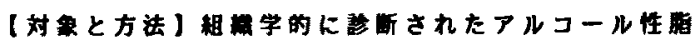
肪䏦 2 (

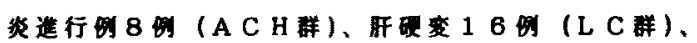

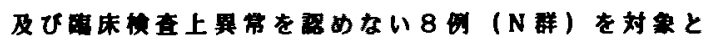
した。血消 B B C は、抗ヒトN型コラゲン $\alpha_{1}$ 頪モ， クローナル抗体を固相に、B B Cに対するモノクロー

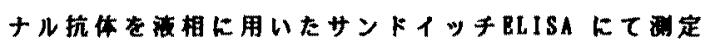
した。旰解バラメータとして、ブロトンビン時間、 血小板数、血消アルフミン、SGOT、SGPT、YGTP、ALP を用いた。

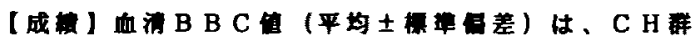
$232 \pm 152 \mathrm{ng} / \mathrm{ml}$ で、A群 3，95、N群 $68 \pm 45$ より角 意に高く、A C H 群 $520 \pm 45$ 、L C 群 $578 \pm 108$ より

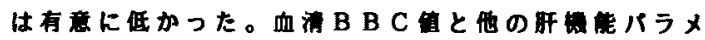
一夕との相的をみると、CH群は、A C H 群、L C 群 とは分布が異なっていた（共分敞分析；p<0.01)。 C H 群では、血消B B C 榇は SGPT $(r=0.42)$ 万よひ

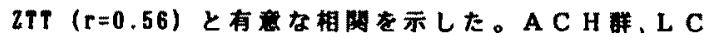
群においては、いずれの腰能バラメータとも有意な 相阙は得られなかつた。

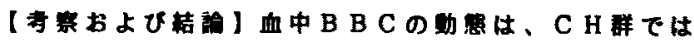

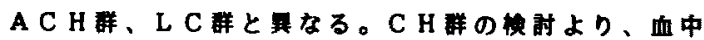
B B C が域死、荻症の活㽖度を一部反映ず可能性は

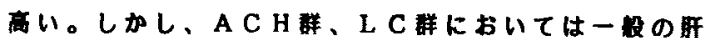
觶パラメータとは相成せす、粗田字的に高度のコラ ゲン增生を伴うこれらの群で特に高稙をとることは注

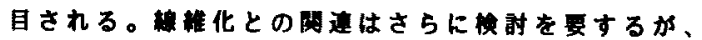

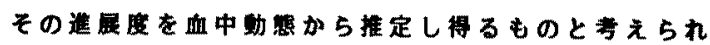
た。 
31巻 suppl. (1990)

445 障害ヒト肝組瀻におけるブロコラーダンお 上びブロリン水酸化醭素 mRNAの局在 山田裕之, 間 武雄, 田口克司, 浅野伍朗 (日本医科大学病理学教室)

【目的】コラーゲンは, 䀒線維化の進展にとすない増 加し，病㦔に密接に関与しているてとが知られている。 徒来，肝組維におけるコラーダン應生細胞は，線維茅 細胞，伊東細胞などの間葉系細胞と考えられていた。 しかし， in vitroで細胞にコラーゲン合成が確認 されて以来，上皮系である肝細胞による invivoでの コラーゲン合成が予想されるようになり，近年，免疫 組䋖化学的にる，ヒト胿細胞中のコラーグンお上びコ ラーゲン合成のkey enzyme でるブロリン水酸化醇 素の局在が報告されるよらになった。我々は，价 situ ハイブリダイゼーション法を用い, ヒト肝生検 組織におけるタイブ I，Wブロコラーゲン，ブロリン 水酸化䣼素 mRNA の局在を観察し，肝細胞のコラー ゲン合成能につんて検討した。

【方法】材料は，ウイルス性传性肝炏，訮硬变症およ びフルコール性肝障害患者の肝生検組絊を用いた。 $4 \%$ バラフォルム固定凍結切片およびフォルマリン固 定バラフィン切片を作成し，抗タイブ ン抗体，抗ブロリン水酸化醭素抗体を用いその局在 を検討した。Insitu ハイブリダイゼーションのブロ ーブには,タイブIIフロコラーゲン cDNA (Dr. Rami rez 上り供与)，タイブVブロコラーゲン c DNA(Dr. Wood 【り供与）およびブロリン水酸化醉素 $\beta$ ーサブュニッ トcDNAを用hた。非放射性のシゴキシダニンでブ ローブを標識しハイブリダイぜーションを行ん，抗シ ゴキシゲニン抗体を反応啳発色し観察した。

【成䋖】タイブI，Vブロコラーゲンお上びブロリン

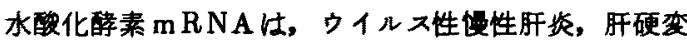

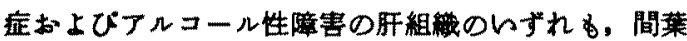
系細胞のみならず肝細胞にすその局在がみられた。ま た，これら mRNA 陽性細胞はんすれる，ウイルス性 研奖ては門脈域周囲のコラーゲン合成が六進している と考えられる部位に比較的多く存在し，それ以外の部 位には散在性に観察された。一方，フルコール性訮障 害て死早期上り，門脈城周囲，中心髅脈周囲だけでな く小葉全体に多数の陽性細胞が認められた。線維化の 進んだ状賏てす，ウイルスに上るるのと比へるとアル コールに起因する肝障害の方が陽性細胞数が多い傾向 がみられた。

【結論】これらの結果より，肝䋖胞るヒト障害肝にお んてコラーゲンを合成し，所線維化の進展に関与して らると考えられた。そして、アルコール性障害肝では, 伊東細胞，類洞内皮細胞ととすに肝細胞が，肝細胞周 囲性線維化や，類洞の毛細血管化に関与している可能 性が示唆された。
446 Histo in situ Hybridizationによるもト

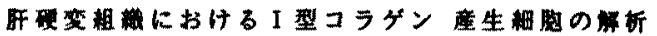

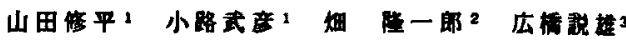

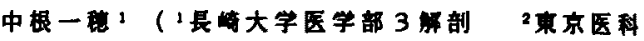

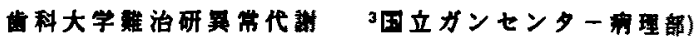

[目的]肝硬变で结】型およびII型コラダンが

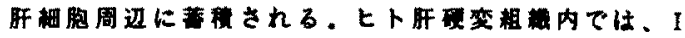

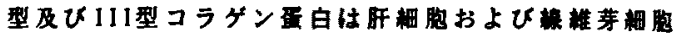
内に免柤化学的に局在が泟明されている。しかし、 特定の蛋白の存在が必をしもたの湅胸内での合成を意 味しないことから、今回我タは、肝砤变時にI型コラ

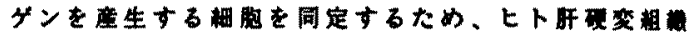
での㑑々の湅慗にお什るI型コラダン造伝子 m R N A の発現状況を、非放射性 D N A フローフを用いた Histo in situ hybridization 法にて模暏した。

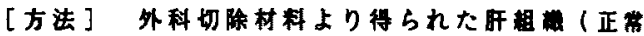

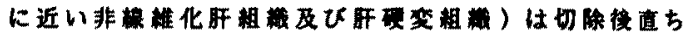

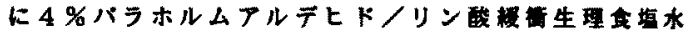

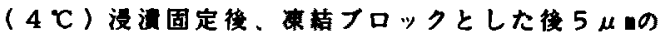

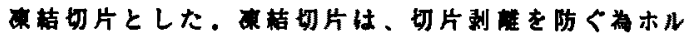
ムフルデヒトで固定したぜラチン処理スライドタラス に貼付した，I型コラダンm R N Aの检出にはブロー フとしてヒトI型コラダンのブロ 及びトI型コラゲンのプロ $\alpha 2$ (I) 外照射により TーTダイマー（チミン二年体）化し たものを用い、さらに対照プローフとして Lanbda D NAを同しく紫外数照射にて TーTダイー化したし

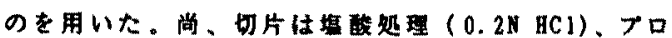

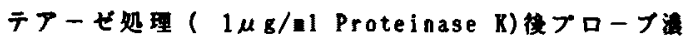
度 $4 \mu \mathrm{g} / \Omega 1$ に $40 \%$ ホルムアミド存在下37とにて 15 時间八イフリタイゼーションを行ない、その後 ーTタイマーに村する抗体を用いて酸来抗体间接法を 行ない旰粗ににおけるI型コラダン m R Nの相照内

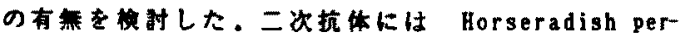
oxidase（H R P) が算就してあり、HRP活性は DAB

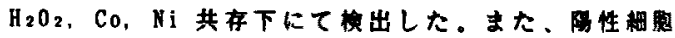

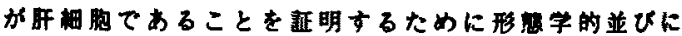

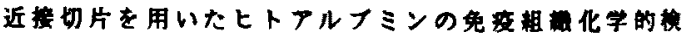
村を行なった。

[成練] 正常に近い非被椎化肝祖部位ではクリ ソン零の線椎芽細胞のみにI型コラダンm R N A

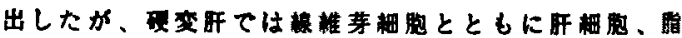
肪接取湅胞にもI型コラダンm R N A゙模出された。

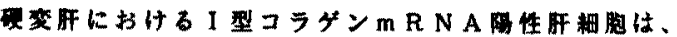

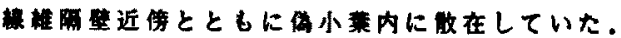

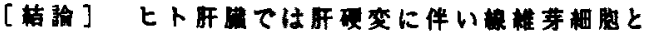

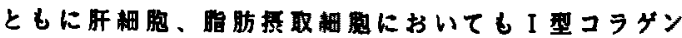

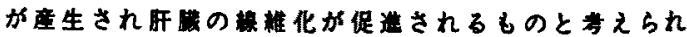
了. 